\title{
Effects of a windthrow disturbance on the carbon balance of a broadleaf deciduous forest in Hokkaido, Japan
}

\author{
K. Yamanoi ${ }^{1}$, Y. Mizoguchi ${ }^{1}$, and H. Utsugi ${ }^{2}$ \\ ${ }^{1}$ Hokkaido Research Center, Forestry and Forest Products Research Institute, 7 Hitsujigaoka, \\ Toyohira-ku, Sapporo, 062-8516, Japan \\ ${ }^{2}$ Forestry and Forest Products Research Institute, Tsukuba, 305-8687, Japan \\ Correspondence to: K. Yamanoi (yamanoi@affrc.go.jp)
}

Received: 3 April 2015 - Published in Biogeosciences Discuss.: 9 July 2015

Revised: 8 November 2015 - Accepted: 16 November 2015 - Published: 1 December 2015

\begin{abstract}
Forests play an important role in the terrestrial carbon balance, with most being in a carbon sequestration stage. The net carbon releases that occur result from forest disturbance, and windthrow is a typical disturbance event affecting the forest carbon balance in eastern Asia. The $\mathrm{CO}_{2}$ flux has been measured using the eddy covariance method in a deciduous broadleaf forest (Japanese white birch, Japanese oak, and castor aralia) in Hokkaido, where incidental damage by the strong Typhoon Songda in 2004 occurred. We also used the biometrical method to demonstrate the $\mathrm{CO}_{2}$ flux within the forest in detail. Damaged trees amounted to $40 \%$ of all trees, and they remained on site where they were not extracted by forest management. Gross primary production (GPP), ecosystem respiration ( $\mathrm{Re})$, and net ecosystem production were 1350,975 , and $375 \mathrm{~g} \mathrm{C} \mathrm{m}^{-2} \mathrm{yr}^{-1}$ before the disturbance and 1262, 1359, and $-97 \mathrm{~g} \mathrm{C} \mathrm{m}^{-2} \mathrm{yr}^{-1} 2$ years after the disturbance, respectively. Before the disturbance, the forest was an evident carbon sink, and it subsequently transformed into a net carbon source. Because of increased light intensity at the forest floor, the leaf area index and biomass of the undergrowth (Sasa kurilensis and S. senanensis) increased by factors of 2.4 and 1.7, respectively, in 3 years subsequent to the disturbance. The photosynthesis of Sasa increased rapidly and contributed to the total GPP after the disturbance. The annual GPP only decreased by $6 \%$ just after the disturbance. On the other hand, the annual Re increased by $39 \%$ mainly because of the decomposition of residual coarse-wood debris. The carbon balance after the disturbance was controlled by the new growth and the decomposition of residues. The forest management, which resulted in the dead trees remaining at the study site, strongly affected the carbon
\end{abstract}

balance over the years. When comparing the carbon uptake efficiency at the study site with that at others, including those with various kinds of disturbances, we emphasized the importance of forest management as well as disturbance type in the carbon balance.

\section{Introduction}

Forests play a particularly important role in terrestrial carbon sequestration because almost $90 \%$ of all biomass is stored in trees and $50 \%$ of terrestrial organic matter is stored in forest (Körner, 2003). A net carbon uptake or release by forests has an impact on the atmospheric $\mathrm{CO}_{2}$ concentration. Therefore, to determine the carbon balance in various forest ecosystems, eddy covariance measurements have been performed (Valentini et al., 2000; Law et al., 2002; Hirata et al., 2008). These measurements indicated that most forests are in a carbon sequestration stage when forest destruction is not taken into account. The carbon balance in such forests is stable, with anomalies occurring in relation to interannual weather conditions. The net carbon uptake is a slow phenomenon because of tree growth, and carbon accumulation into the soil is tied to forest age. In contrast, net carbon releases tend to result from forest disturbances. Schulze (2006) classified ecosystem disturbances as follows: (1) continuous forcing of the $\mathrm{C}$ and $\mathrm{N}$ cycles (e.g., by temperature or $\mathrm{CO}_{2}$ increase), (2) disturbances that act as a disruption of $\mathrm{C}$ and $\mathrm{N}$ cycles (e.g., by insects or windthrow), or (3) disturbances where the $\mathrm{C}$ and $\mathrm{N}$ are exported from the ecosystem (e.g., by fire and harvesting). The first disturbance type may impose persis- 
tent stresses on the ecosystem, gradually changing the carbon balance. The second type may impose damage within a day (e.g., by windthrow) or within a few months (e.g., by impact by insects). All dead-wood matter resulting from the impact may remain on site if not extracted by forest management. The third type may impose impacts within a few hours (e.g., by fire) or within a few months (e.g., by forest harvesting) and bypass the heterotrophic chain of respiration. For example, in a fire, carbon fixed over a period of a few decades to 300 years may be released within a few hours. In cases of disturbance, except for fire, most carbon release occurs with some delay, but the release is nevertheless rapid relative to the net carbon uptake. Magnani et al. (2007) demonstrated the age-related dynamics of the carbon balance following a disturbance (harvesting) in five forest ecosystems across Europe. After each event, the forest is typically a net carbon source over the initial years, followed by a broad peak in carbon sequestration. Amiro et al. (2010) summarized more than 180 site years of eddy covariance measurements of carbon flux made at forest chronosequences after disturbances including fire, harvest, thinning, insect infestations, and windthrow in North America. Net ecosystem production (NEP) showed a carbon loss from all ecosystems following a stand-replacing disturbance, only returning to a carbon sink after 20 years for all ecosystems and after 10 years for most. Goetz et al. (2012) assessed the forest carbon dynamics following disturbances of fire, insects, and harvest in North America. They identified disturbance severity and history as key factors but recognized that there are highly uncertain factors driving post-disturbance carbon source-sink dynamics across all disturbance types. Therefore, the longterm carbon balance is affected by a disturbance regime, which shows special and temporal dynamics and is composed of frequency, return interval, rotation period, size, intensity, severity, and residuals (Turner, 2010).

Although many types of disturbance have an influence on the carbon balance, windthrow is one of the most influential ones. However, few reports have described the direct quantification of the change in the carbon balance caused by windthrow. In the USA, windthrow events by hurricanes are intense and frequent. Chambers et al. (2007) estimated that Hurricane Katrina in 2005 destroyed 320 million large trees, corresponding to a total biomass loss of $105 \mathrm{Tg} \mathrm{C}$. This amount is equivalent to $50-140 \%$ of the net annual carbon sink in US forests. In western Europe, windthrow storm events are important forest disturbances (Nilsson et al., 2004; Usbeck et al., 2010). Lindroth et al. (2009) reported that storm Gudrun, which hit Sweden in 2005, resulted in approximately 66 million $\mathrm{m}^{3}$ of windthrown stem wood over an area of approximately $2720 \mathrm{~km}^{2}$. The reduction in the carbon sink scaled to the whole windthrown area was estimated at approximately $3 \mathrm{MtC}$ during the first year. Storm Lothar in 1999 reduced the European carbon balance by approximately $16 \mathrm{MtC}$, equating to approximately $30 \%$ of the net biome production in Europe. In European Russia, the spruce forests released $180 \mathrm{~g} \mathrm{Cm}^{-2}$ (Schulze et al., 1999) and $192 \mathrm{~g} \mathrm{Cm}^{-2}$ (Knohl et al., 2002) over a 3-month period in summer 2 years after a windthrow event.

Windthrow is the most significant disturbance in eastern Asia, which is a humid region. Typhoons are a typical windthrow event in Japan, causing catastrophic damage to forest ecosystems. For example, Typhoon Toyamaru, which was the most severe typhoon event in Japan's recorded history, damaged $7500 \mathrm{~km}^{2}$ of forest area and 27 million $\mathrm{m}^{3}$ of stem wood in Hokkaido, the northernmost island of Japan, in 1954 (Tamate et al., 1977). In 2004, Typhoon Songda (the trigger event for this study) also hit Hokkaido and damaged $370 \mathrm{~km}^{2}$ of forest area; the damage caused dramatic but was only $5 \%$ of that of Typhoon Toyamaru (Hokkaido Forest Research Institute, 2004). There are few reports detailing long-term monitoring of the carbon flux using the eddy covariance method in wind-disturbed forest ecosystems. Sano et al. (2010) reported that NEP during the growing season changed from 159 before to $-80 \mathrm{~g} \mathrm{C} \mathrm{m}^{-2}$ after disturbances of the Japanese larch forest. Ito (2010) evaluated the impact of defoliation caused by a typhoon event on the carbon balance in a deciduous broadleaf forest. The biomass of leaves decreased by 10-20\%, lowering the canopy carbon gain by nearly $200 \mathrm{~g} \mathrm{Cm}^{-2} \mathrm{yr}^{-1}$. While IPCC (2013) reported that the increases in frequency and intensity of tropical cyclone were low confidence in future projections, Tsuboki et al. (2015) demonstrated increases in typhoon intensity with global warming in the western North Pacific. An occasional large windthrow event may partly affect the interannual variation in the terrestrial carbon balance. Although a disturbance is a complicated process associated with temporal and spatial variation, it is uncommon for flux measurement to continue for an extended period both before and after a disturbance.

In this study, the uptake and release of $\mathrm{CO}_{2}$ by a forest ecosystem has been measured since the year 2000 using the eddy covariance technique. Kitamura et al. (2012) reported on the carbon balance of this forest for the first 4 years (2000-2003). Seasonal and interannual variations in $\mathrm{CO}_{2}$ flux were evaluated and characterized. We used the biometrical method with the eddy covariance method to demonstrate the detailed carbon balance in the forest. By coincidence, the monitored forest was damaged by the strong Typhoon Songda in 2004. Subsequently, we focused on the change in the carbon balance under the natural revegetation process resulting from the windthrow disturbance.

\section{Materials and methods}

\subsection{Site description}

This study was conducted at the Sapporo forest meteorology research site $\left(42^{\circ} 59^{\prime} \mathrm{N}, 141^{\circ} 23^{\prime} \mathrm{E}\right.$; $182 \mathrm{ma.s.l}$.; AsiaFlux site code: SAP) in Sapporo, Japan. The site is lo- 
cated within the Hitsujigaoka Experimental Forest (147 ha) of the Hokkaido Research Center, Forestry and Forest Products Research Institute (FFPRI). The mean annual temperature is $7.3^{\circ} \mathrm{C}$, and the monthly mean temperature ranges from $-5.1{ }^{\circ} \mathrm{C}$ in January to $20.1^{\circ} \mathrm{C}$ in August. The annual precipitation is $945 \mathrm{~mm}$, and maximum snow depth was $1.37 \mathrm{~m}$ in February 2000 (Mizoguchi et al., 2014a). The terrain gently slopes to the northwest, with an average inclination of $6.5^{\circ}$. The soil parent material of this area is predominantly volcanic ash, and the soil type is Andosol (Ishizuka et al., 2006). The forest type is mature secondary deciduous broadleaf forest, regenerated after wildfires in the late 19th century $(1874,1883,1887$, and 1888). The forest represents the transition stage from an early successional Japanese white birch (Betula platyphylla var. japonica) to mid- and late-successional species (Japanese oak (Quercus mongolica var. grosseserrata), castor aralia (Kalopanax septemlobus (Thunb.) Koidz), painted maple (Acer mono), and Japanese linden (Tilia japonica)) forest. The first two species accounted for $>75 \%$ of the basal area in 2003 (Utsugi et al., 2005). Dwarf bamboo (Sasa kurilensis and $S$. senanensis) dominantly covered the forest floor, and some herbaceous species partly covered it. The stand density and mean tree height over $5 \mathrm{~cm}$ diameter at breast height (DBH) were 672 trees ha $^{-1}$ and $18.3 \mathrm{~m}$ in 2003, respectively. The oldest white birch was 90 years old in 2002 .

The strong Typhoon Songda (18th of the season) struck northern Japan on 8 September 2004. Many canopy trees were uprooted or broke off by strong winds at the SAP site (Fig. 1). Prior to the windthrow disturbance, the canopy was almost closed with the dominant tree species. The subsequent typhoon removed $33 \%$ of the tree canopy and $28 \%$ of tree biomass (Takahashi et al., 2009; Utsugi et al., 2009). Large canopy gaps were formed at the site. However, the damage was heterogeneously distributed throughout the forest. All dead trees remained on site and were not extracted by forest management. The forest began recovering under the natural mechanisms of the ecosystem.

\subsection{Flux and meteorological measurements}

$\mathrm{CO}_{2}$ flux was measured using an eddy covariance system at a height of $28.5 \mathrm{~m}$ on a $41 \mathrm{~m}$ tall scaffold tower at the center of the SAP site. The system consisted of a three-dimensional sonic anemometer (SAT: DA600-3T or DA600-3TV, SONIC, Japan) that measured wind vector components and a closedpath infrared gas analyzer (IRGA: LI-6262, LI-COR, USA) that measured atmospheric $\mathrm{CO}_{2}$ concentrations. An aspirated thermohygrometer (HMP-45A, Vaisala, Finland) that measured relative humidity and air temperature was mounted at the same height as the SAT. The air inlet was installed behind the SAT, and air was drawn to the IRGA in a cabin located at ground level. The inlet and IRGA were connected by a polytetrafluoroethylene tube of $40 \mathrm{~m}$ in length and $6 \mathrm{~mm}$ in inner diameter. Sample air was pushed into a mass flow

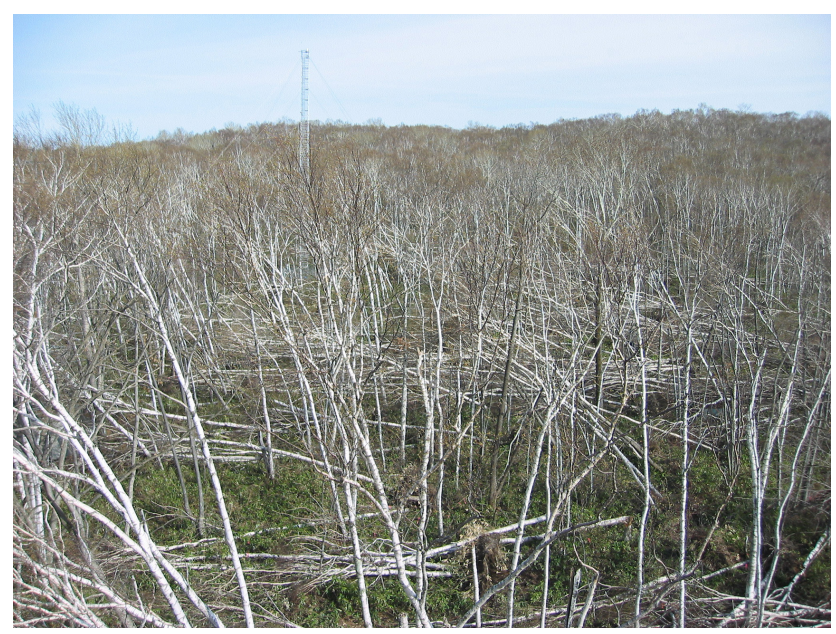

Figure 1. Southeast-facing aspect at a deciduous broadleaf forest in Sapporo, Japan. This forest was disturbed by strong wind in September 2004. The picture was taken on 12 May 2005.

controller at a flow rate of approximately $9.5 \mathrm{~L} \mathrm{~min}^{-1}$ and was regulated at $2.0 \mathrm{~L} \mathrm{~min}^{-1}$. The residual air was released from an exhaust port. Water vapor in the sample air was removed with an air dryer (MD-110-48F, Perma Pure, USA). The IRGA was calibrated automatically once a day using zero and $\mathrm{CO}_{2}(450 \mathrm{ppm})$ standard gases in an air balance. The sensor signals were recorded every $0.2 \mathrm{~s}(5 \mathrm{~Hz})$ using a digital data logger (DRM3, TEAC, Japan). Details of the flux system are reported in the study by Yasuda and Watanabe (2001). The system in FFPRI FluxNet sites, including the SAP site, was subsequently modified for long-term flux monitoring (Ohtani et al., 2001). Vertical profiles of the $\mathrm{CO}_{2}$ concentration were measured using another IRGA (LI-6262, LI-COR) with a valve-switching unit at five sampling heights (3.6, 10.5, 16.3, 20.1, and 29.6 m). Sampling air from each height was dehumidified using the same air dryer, and was pushed into the IRGA at a flow rate of $1.8 \mathrm{~L} \mathrm{~min}^{-1}$. The sampling interval of each height was $2 \mathrm{~min}$, and therefore one cycle of the system equated to $10 \mathrm{~min}$. The IRGA was calibrated automatically once a day.

Meteorological conditions were measured in and above the forest canopy. Air temperature and humidity were measured using an aspirated thermohygrometer (HMP-45D, Vaisala) at $29.6 \mathrm{~m}$. Photosynthetically active radiation (PAR) was measured using quantum sensors (LI-190, LI-COR) at the top of the tower $(41.3 \mathrm{~m})$ and above the undergrowth $(2.4 \mathrm{~m})$.

The observations commenced in August 1999. The observational infrastructure was destroyed by the typhoon in 2004 and reconstructed in the spring of 2005 (Nakai et al., 2004). The studies by Kitamura et al. (2012) and Mizoguchi et al. (2014a) provide a more detailed description and additional information regarding the meteorological measurements. 


\subsection{Data processing and analysis}

The $\mathrm{CO}_{2}$ flux above the canopy $(\mathrm{Fc})$ was calculated every $30 \mathrm{~min}$ using the eddy covariance technique. Threedimensional coordinate rotation (McMillen, 1988), corrections for the effects of lateral wind on sonic velocity and of water vapor on temperature (Kaimal and Gayner, 1991; Hignett, 1992), and the density correction theory of Webb et al. (1980; WPL correction) were applied. The attenuation loss of high-frequency fluctuations in the $\mathrm{CO}_{2}$ concentration in the closed-path system (Leuning and Moncrieff, 1990) was corrected with an empirical transfer function. Linear trends were removed. The lag time of the sampling of air from the inlet to the cell of the IRGA was optimized for the first extremum of cross-correlation between the vertical wind velocity and the $\mathrm{CO}_{2}$ concentration. Tests were run on all data to screen for data quality; one method used was visual inspection of the raw data, whereas the other was a series of tests in accordance with the quality control procedure (Foken and Wichura, 1996; Vickers and Mahrt, 1997). The proportion of missing observations due to instrument malfunction and maintenance was $10 \%$, and the amount of data rejected by the quality test mentioned above was $12 \%$. Using the $\mathrm{CO}_{2}$ profile data, the rate of change in $\mathrm{CO}_{2}$ storage in the canopy (Sc) was calculated every $30 \mathrm{~min}$ from the temporal change in $\mathrm{CO}_{2}$ storage in an air column between ground level and the height of the eddy covariance systems.

Net ecosystem exchange (NEE) is defined as the sum of $\mathrm{Fc}$ and Sc during the average period and NEP is equal to negative NEE:

$\mathrm{NEP}=-\mathrm{NEE}=-(\mathrm{Fc}+\mathrm{Sc})$.

NEE was underestimated during low-turbulence atmospheric conditions, such as stable night periods. We applied data screening using the threshold of friction velocity $\left(u_{*}\right)$ to exclude flux under such conditions (Massman and Lee, 2002). To determine the $u_{*}$ threshold, we examined NEE at night, which decreased greatly with the depression of $u_{*}$. In this study, we selected $0.29 \mathrm{~m} \mathrm{~s}^{-1}$ before the disturbance and $0.31 \mathrm{~m} \mathrm{~s}^{-1}$ after the disturbance as the $u_{*}$ threshold. NEE was equal to ecosystem respiration $(\mathrm{Re})$ during the night. We expressed Re in terms of air temperature $(\mathrm{Ta})$ :

$\mathrm{Re}=R_{0} Q_{10}^{\mathrm{Ta} / 10}=R_{0} \exp (k \cdot \mathrm{Ta})$,

where $R_{0}$ is the respiration rate at $0^{\circ} \mathrm{C}$ and $Q_{10}$ is the increase in respiration for every $10^{\circ} \mathrm{C}$ rise in temperature. $R_{0}$, $Q_{10}$, and $k$ were derived for three periods in a year (growth period, defoliation period without snow, and defoliation period with snow) and were constants in each period. Daytime Re was also calculated using Eq. (2), with the assumption that Eq. (2) is valid during the day. Daytime was defined as the period from sunrise to sunset.

Data gaps during the nighttime NEP were infilled with Re values calculated using Eq. (2), and those during the daytime were filled with NEP calculated as follows:

$\mathrm{NEP}=\left(a^{\prime} \cdot \mathrm{Pd} \cdot \mathrm{Ag}_{\max }\right) /\left(\mathrm{Ag}_{\max }+a^{\prime} \cdot \mathrm{Pd}\right)+c$,

where $a^{\prime}$ is the light-use efficiency, Pd is the downward PAR above the canopy, $\mathrm{Ag}_{\max }$ is the light-saturated NEP, and $c$ is the daytime respiration rate. The variables $a^{\prime}, \mathrm{Ag}_{\max }$, and $c$ are constants and were derived daily for the previous 5 days. Gross primary production (GPP) was estimated as follows:

$\mathrm{GPP}=\mathrm{NEP}+\mathrm{Re}$.

\subsection{Biometric measurements}

The plots for biometric measurement were established near the observation tower. We used a 0.25 ha $(50 \mathrm{~m} \times 50 \mathrm{~m})$ plot established in 1978 before the disturbance and set up a 1.6 ha plot composed of 40 subplots $(20 \mathrm{~m} \times 20 \mathrm{~m})$ after the disturbance. The DBHs of all trees that were $>5 \mathrm{~cm}$ in the plots were measured every year from 2000 to 2012 . Tree heights $(H)$ of all trees in the plot were measured in 2002. The relationships between $H$ and DBH for each species were formulated. During the summer of 2001 and 2003, 26 sample trees were subjected to destructive analysis. Eight trees of birch, 10 of oak, and 8 of castor aralia were used to determine the allometrics between biomasses and tree dimensions. The sample trees were felled at a height of $0.3 \mathrm{~m}$, and DBH and $H$ were measured. The crowns were divided into $1 \mathrm{~m}$ thick strata from the stump height $(0.3 \mathrm{~m})$ to the treetop. Each stratum was divided into the tree biomass components of stem, branch, and leaf, and the fresh weight of each component was immediately measured. The dry weights of each component were calculated from the fresh weight and water content. These weights were summed for the entire tree, and the total dry weight of each component scaled positively with tree dimensions, i.e., $\mathrm{DBH}^{2} \times H$ for stem and branch and $\mathrm{DBH}$ for leaf in the allometric equations.

Biomass production at the stand level was estimated by summing up the biomass production of individual trees, which was obtained by inventorying the dimensions of trees in the study plots. The litterfall was collected monthly using 50 traps of $0.48 \mathrm{~m}^{2}$ from 2000 to 2003 in the growing seasons. In the snowy seasons, a large plastic sheet $(20 \mathrm{~m} \times 20 \mathrm{~m})$ was set up on the ground. All branches that had dropped on to the sheet were collected as representative of litterfall during the snowy seasons. The litterfall was oven-dried at $70^{\circ} \mathrm{C}$ and separated into leaf, branch, and other components (seed, flower, and bud) for weighing.

The aboveground net primary production (ANPP) in a year was calculated as follows (Clark et al., 2001):

$\mathrm{ANPP}=\Delta y+\mathrm{Lf}+G=\left(\mathrm{AGB}_{\mathrm{t} 2}-\mathrm{AGB}_{\mathrm{t} 1}\right)+\mathrm{Ld}+\mathrm{Lf}+G$,

where $\Delta y$ is the aboveground biomass increment of surviving and recruiting trees, $\mathrm{Lf}$ is litterfall from living trees, $G$ is predation by herbivorous insects and was ignored in the 
present study, and Ld is the stem and branch biomass of dead trees produced in a year. AGB is the aboveground biomass of living trees, and subscripts imply times at the beginning (t1) and end ( $\mathrm{t} 2$ ) of a year. The aboveground net biomass increment $(\mathrm{ANBI})$ is defined as $\mathrm{AGB}_{\mathrm{t} 2}-\mathrm{AGB}_{\mathrm{t} 1}$.

The ratio of root to stem biomass used was 0.317 (Utsugi et al., 2007), and the carbon content in the soil used was $18 \mathrm{~kg} \mathrm{C} \mathrm{m}^{-2}$ (Sakata et al., 2010). We assumed that the parameters of allometric equations for biomass components, the ratio of root to stem biomass, and the carbon content in the soil were constant and equal before and after the windthrow disturbance.

The carbon content of stems, branches, and leaves was determined using an NC analyzer (Sumigraph NC-80, Shimizu, Kyoto, Japan) during destructive sampling. The carbon content of stems and branches was $48.9 \%$ by dry weight for birch and oak, whereas that of leaves was 52.4, 48.5, and $48.3 \%$ for birch, oak, and castor aralia, respectively. These values were very near the $50 \%$ that had been assumed as the carbon content of biomass in previous reports (Smithwick et al., 2002; Lamlon and Savidge, 2003). We assumed the ratio of carbon to biomass to be 0.5 for stem, branch, and leaf components.

Leaf area index of canopy tree $\left(\mathrm{LAI}_{\text {tree }}\right)$ was estimated by the combination of light interception and the leaf litter measurements. For the light interception measurements, the downward PAR was measured above the forest canopy and the undergrowth using the quantum sensor. Under cloudysky conditions, Beer's law of light penetration was applied within the canopy layer as follows:

$\mathrm{LAI}_{\text {tree }}=-F \ln \left(\mathrm{Pd}_{0} / \mathrm{Pd}\right)$,

where $\operatorname{Pd}_{0}$ is the PAR above the undergrowth and $F$ is the light transmission coefficient of the canopy. The value of $F$ was assumed constant throughout the year and was estimated by substituting values of PAR and LAI obtained by leaf litter measurements in 2000 and 2001.

Six small plots $(2 \mathrm{~m} \times 2 \mathrm{~m})$ under different disturbance intensities were selected to measure the biomass and the leaf area index of Sasa in 2006, 2008, 2009, and 2012. Therefore, the plots were influenced by the different light conditions. All aboveground biomass of Sasa in the plot was separated into leaf and culm, and the root of Sasa was collected from a part of the plot. All samples were dried and weighed. The area of 10 leaves that were randomly selected was measured. Values of $\mathrm{Pd}_{0}$ were measured above Sasa at each plot. The leaf area index of Sasa ( $\mathrm{LAI}_{\text {Sasa }}$ ) and the biomass of Sasa (SBM) were increased with the transmittance $\left(\mathrm{Pd}_{0} / \mathrm{Pd}\right)$ linearly (Utsugi et al., 2013; Mizoguchi et al., 2014b) and were estimated at all the subplots.
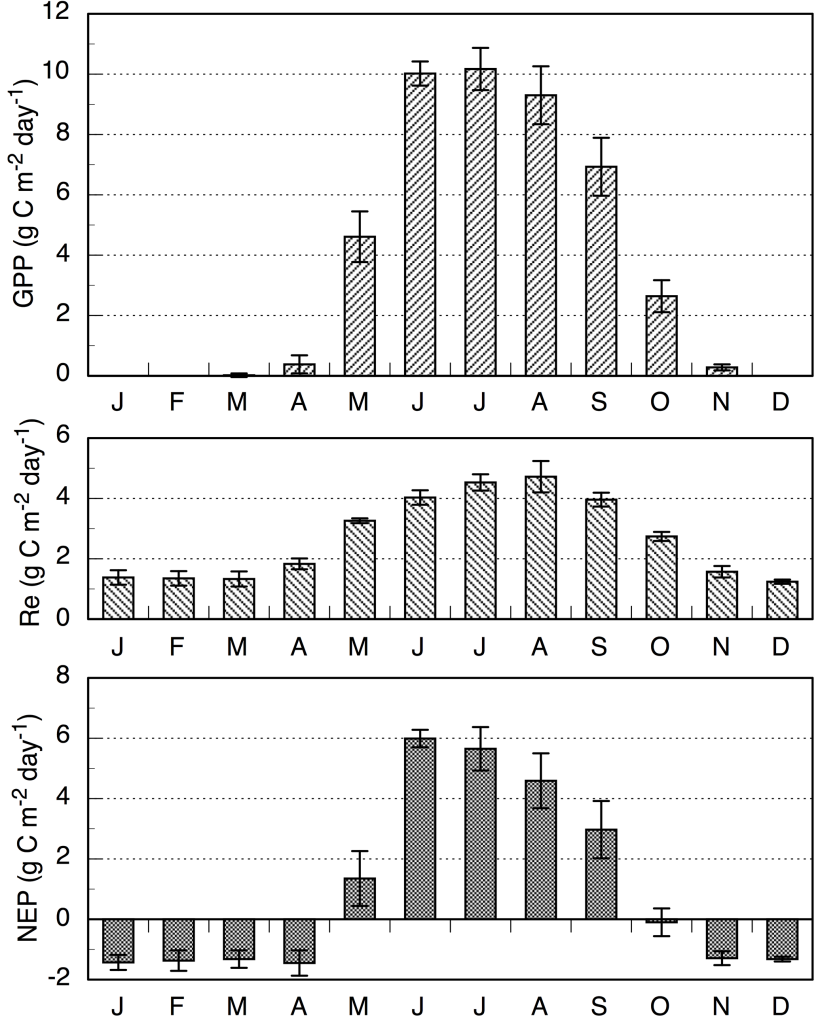

Figure 2. Seasonal variations in gross primary production (GPP), ecosystem respiration (Re), and net ecosystem production (NEP) before the disturbance between 2000 and 2003. The fluxes represent 4-year monthly means and standard deviations of daily values $\left(\mathrm{gC} \mathrm{m}^{-2} \mathrm{day}^{-1}\right)$.

\section{Results}

\subsection{Seasonal changes in $\mathrm{CO}_{2}$ flux}

At the study site, the bud burst started at the end of April and the beginning of May, and all leaves of canopy trees turned yellow during October. Sasa undergrowth was buried in snowpack from mid-December to the beginning of April. Seasonal changes in GPP, Re, and NEP before the disturbance, represented by the monthly means of the daily fluxes, are shown in Fig. 2. GPP increased after bud burst, was almost constant from June to mid-August, and decreased gradually in autumn. GPP peaked in July and was 0 during the snowy defoliation period. Re increased after snow thaw with rising air temperature, peaked in August, and maintained an almost constant value of $1.3 \mathrm{~g} \mathrm{C} \mathrm{m}^{-2} \mathrm{day}^{-1}$ during the snowy defoliation period from December to March. NEP increased rapidly in May and peaked in June, decreasing gradually from mid-summer to autumn. A positive NEP value was observed from May to September and a negative value from October to April, with the positive and negative values representing $\mathrm{CO}_{2}$ uptake to and release from the forest, respectively. During the defoliation period, the forest was a weak 

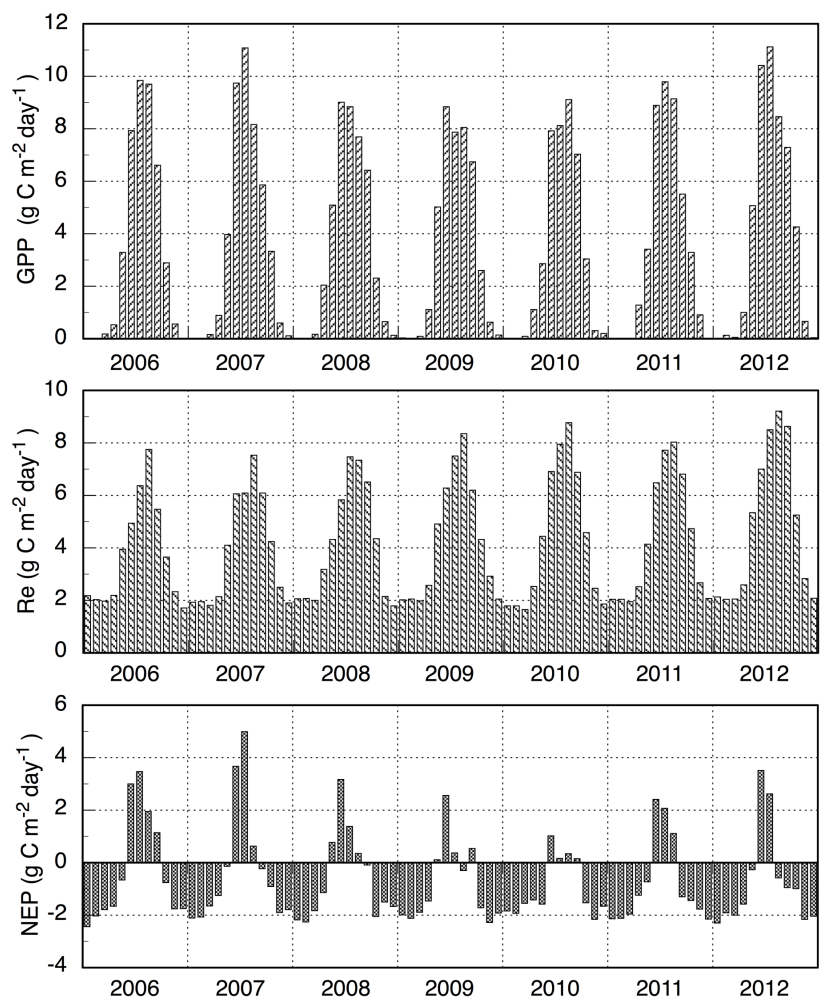

Figure 3. Seasonal and interannual variations in gross primary production (GPP), ecosystem respiration (Re), and net ecosystem production (NEP) after the disturbance between 2006 and 2012.

source of $\mathrm{CO}_{2}$, at a rate of $-1.4 \mathrm{~g} \mathrm{Cm}^{-2} \mathrm{day}^{-1}$. Maximum values of the monthly means of GPP, Re, and NEP were 10.2, 4.7 , and $6.0 \mathrm{~g} \mathrm{C} \mathrm{m}^{-2} \mathrm{day}^{-1}$, respectively.

The seasonal changes in the $\mathrm{CO}_{2}$ budgets after the disturbance are shown in Fig. 3. The shapes of seasonal trends in GPP and Re after the disturbance were similar to the trends before the disturbance. Averaged maximum GPP and Re from 2006 to 2008 were 10.0 and $7.6 \mathrm{~g} \mathrm{C} \mathrm{m}^{-2} \mathrm{day}^{-1}$, respectively, and they were 1.0 and 1.6 times greater, respectively, than those before the disturbance. During the snowy defoliation period, the average Re from 2006 to 2008 was $2.0 \mathrm{~g} \mathrm{C} \mathrm{m}^{-2}$ day $^{-1}, 1.5$ times greater than Re before the disturbance. The disturbed forest absorbed $\mathrm{CO}_{2}$ for 3 to 4 months after the disturbance as opposed to 5 months before the disturbance. In particular, $\mathrm{CO}_{2}$ uptake only occurred for 2 months in 2012. The average NEP during the defoliation period from 2006 to 2008 was $-1.8 \mathrm{~g} \mathrm{Cm}^{-2}$ day $^{-1}$.

\subsection{Interannual changes in $\mathrm{CO}_{2}$ flux}

Figure 4 shows interannual variation in GPP, Re, and NEP from 2000 to 2012. The observations were suspended because of the windthrow disturbance in 2004. Ten months of observations are missing from September 2004 to June 2005; however, 2 years of observations are shown in Fig. 4. The 4-year average annual GPP, Re, and NEP before the distur-

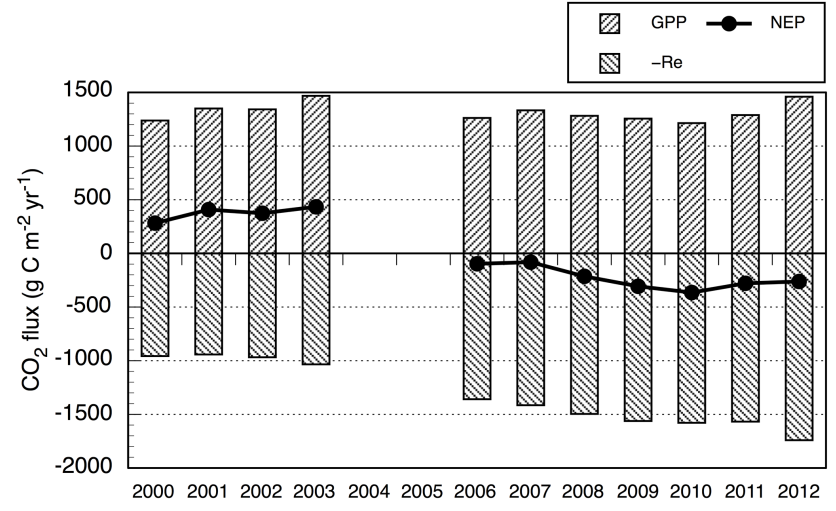

Figure 4. Interannual carbon flux changes in gross primary production (GPP), ecosystem respiration (Re), and net ecosystem production (NEP) before and after the disturbance. The values for the annual sums are missing in 2004 and 2005.

bance were 1350,975 , and $375 \mathrm{~g} \mathrm{Cm}^{-2} \mathrm{yr}^{-1}$, respectively. In 2006, 2 years after the disturbance, the annual GPP decreased to $1262 \mathrm{~g} \mathrm{Cm}^{-2} \mathrm{yr}^{-1}$ and annual Re increased to $1359 \mathrm{~g} \mathrm{Cm}^{-2} \mathrm{yr}^{-1}$, being $6 \%$ smaller and $39 \%$ greater, respectively. The annual NEP changed from a positive value $\left(\mathrm{CO}_{2}\right.$ uptake $)$ to a negative value $\left(\mathrm{CO}_{2}\right.$ release $)$ and was $-97 \mathrm{~g} \mathrm{Cm}^{-2} \mathrm{yr}^{-1}$. The $\mathrm{CO}_{2}$ budget was greatly altered by the disturbance. After the disturbance, these fluxes changed year after year; Re increased gradually and GPP varied in a temporally heterogeneous and complicated manner. NEP represented a weak $\mathrm{CO}_{2}$ release in 2006 and 2007, which subsequently decreased gradually and bottomed out at $-365 \mathrm{~g} \mathrm{Cm}^{-2} \mathrm{yr}^{-1}$ in 2010. NEP increased slightly under the forest restoration processes in 2011 and 2012.

\subsection{Changes in biomass for canopy trees and Sasa}

Changes in AGB, $\Delta y$ (growth of surviving and recruiting trees), and Ld are shown in Fig. 5. The carbon stocks are summarized in Table 1. For a 4-year period from 2000 to 2003, the mean AGB was $9.37 \mathrm{~kg} \mathrm{Cm}^{-2}$, including leaf and branch biomass. The mean AGB of Japanese white birch was $51.6 \%$, and that of Japanese oak was $33.5 \%$ of the mean total AGB before the disturbance. As shown in Table 1, the root biomass was $31.7 \%$ of stem biomass (Utsugi et al., 2007) and soil carbon was $18.0 \mathrm{~kg} \mathrm{Cm}^{-2}$ (Sakata et al., 2010). We assumed that the ratio of root to stem biomass and the soil carbon content after the disturbance were the same as that before the disturbance. After the disturbance, AGB decreased by $40.4 \%$ in 2005 and had evidently stabilized by 2012 .

The $\Delta y$ ranged from 92 to $164 \mathrm{~g} \mathrm{C} \mathrm{m}^{-2} \mathrm{yr}^{-1}$, with a mean value of $140 \mathrm{~g} \mathrm{C} \mathrm{m}^{-2} \mathrm{yr}^{-1}$ before the disturbance. The interannual value of ANBI $(=\Delta y-\mathrm{Ld})$ hovered around 0 , with a mean value of $17 \mathrm{~g} \mathrm{Cm}^{-2} \mathrm{yr}^{-1}$ before the disturbance. This marginally positive value of the mean ANBI was attributed to the negative ANBI of Japanese white birch that occurred over 
Table 1. Carbon stocks at the SAP site before and after the windthrow disturbance. The periods before and after the disturbance are 2000-2003 and 2006-2008, respectively.

\begin{tabular}{lrr}
\hline Carbon stock $\left(\mathrm{kgC} \mathrm{m}^{-2}\right)$ & Before disturbance & After disturbance \\
\hline $\begin{array}{l}\text { Aboveground biomass } \\
\text { of living trees }\end{array}$ & 9.37 & 5.61 \\
Stem & 7.47 & 4.39 \\
Branch & 1.73 & 1.12 \\
Leaf & 0.17 & 0.10 \\
Root biomass ${ }^{1}$ & 2.37 & 1.39 \\
Sasa biomass & 0.72 & 1.20 \\
Soil carbon $^{2}$ & 18. & 18. \\
${ }^{1}{ }^{1}$ Root biomass is $31.7 \%$ of stem biomass (Utsugi et al., 2007). ${ }^{2}$ Soil carbon is quoted \\
from Sakata et al. (2010).
\end{tabular}

the 4-year period, excluding 2001. This negative ANBI value demonstrated that the dead-tree biomass (Ld) was greater than $\Delta y$ for Japanese white birch. However, the ANBI value for Japanese oak and that for the other surveyed species was positive and significantly greater than that for Japanese white birch during the 4-year period. After the disturbance, $\Delta y$ increased and ranged from 92 to $197 \mathrm{~g} \mathrm{Cm}^{-2} \mathrm{yr}^{-1}$. The small number of recruiting trees became countable after the disturbance. On the other hand, the mortality fluctuated irregularly and was greater in 2010 because of minor crown snow damage. No clear differences in ANBI values before and after the disturbance were evident.

Using the linear relation between the SBM and the light transmittance $\left(\mathrm{Pd}_{0} / \mathrm{Pd}\right)$, the three components of SBM were estimated as follows:

$$
\begin{aligned}
& \mathrm{SBMc}=1.039 \times \mathrm{Pd}_{0} / \mathrm{Pd}+0.1717, \\
& \mathrm{SBMl}=0.244 \times \mathrm{Pd}_{0} / \mathrm{Pd}+0.0598, \\
& \mathrm{SBMr}=0.709 \times \mathrm{Pd}_{0} / \mathrm{Pd}+0.3631,
\end{aligned}
$$

where SBMc, SBMl, and SBMr were the culm, leaf, and root (including rhizome) biomass of Sasa, respectively. The total biomass change of Sasa is shown in Fig. 6 assuming that the turnovers of culm, leaf, and root were 9, 3, and 3 years, respectively (Oshima, 1961a, b). The mean SBM before the disturbance was $0.715 \mathrm{~kg} \mathrm{Cm}^{-2}$. SBM increased sharply during the first 3 years after the disturbance and reached $1.408 \mathrm{~kg} \mathrm{C} \mathrm{m}^{-2}$ by the year 2012 .

\subsection{Changes in leaf area index for canopy trees and Sasa}

The leaf area index for canopy tree ( $\left.\mathrm{LAI}_{\text {tree }}\right)$ and Sasa $\left(\mathrm{LAI}_{\text {Sasa }}\right)$ were also estimated from the light transmittance quoted from Mizoguchi et al. (2014b). For the canopy, the transmission coefficients $(F)$ as calculated using Eq. (6) in 2000 and 2001 were 2.91 and 2.41, respectively. We assumed $F$ was constant throughout a year and used a mean value of 2.66 over all the years. For Sasa, we derived a linear correla-
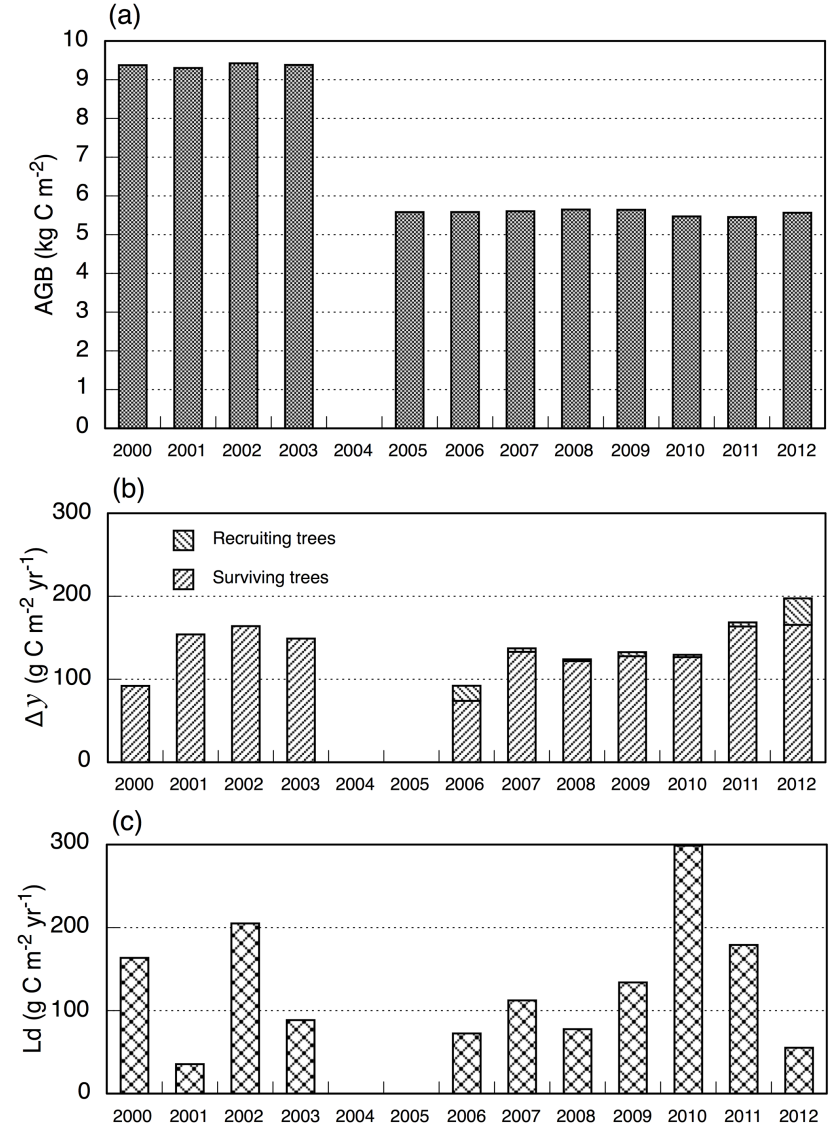

Figure 5. Interannual changes in (a) aboveground biomass of living trees (AGB), (b) aboveground biomass increment of surviving and recruiting trees $(\Delta y)$, and (c) stem and branch biomass of dead trees produced in a year $(\mathrm{Ld})$. The $\Delta y$ of surviving trees from 2000 to 2004 includes the recruiting trees.

tion between $\mathrm{LAI}_{\text {Sasa }}$ and the transmittance as follows:

$\mathrm{LAI}_{\text {Sasa }}=5.71 \times \mathrm{Pd}_{0} / \mathrm{Pd}+1.40$.

For Sasa, the maximum leaf area index of each year was estimated as the mean of $\mathrm{LAI}_{\text {Sasa }}$ over the previous 3 years with the turnover of leaves in mind. Because $\mathrm{Pd}_{0}$ was measured at only one point near the observation tower, where the disturbance was more severe, LAI may not have been rigorously measured after the disturbance.

Interannual changes in the maximum leaf area indexes are shown in Fig. 7, quoted from Mizoguchi et al. (2014b). The value of $\mathrm{LAI}_{\text {tree }}$ after 2005 fell to below a quarter of that before the disturbance. On the other hand, the value of $\mathrm{LAI}_{\text {Sasa }}$ increased by a factor of 2.4 in the 3 years after the disturbance. The value of $\mathrm{LAI}_{\text {Sasa }}$ reached 4.05 in 2007 and maintained a constant value after. The total LAI of the forest just after the disturbance fell to about half, and then, from 2007 to 2012 , it increased to a value of approximately $70 \%$ of that before the disturbance. 


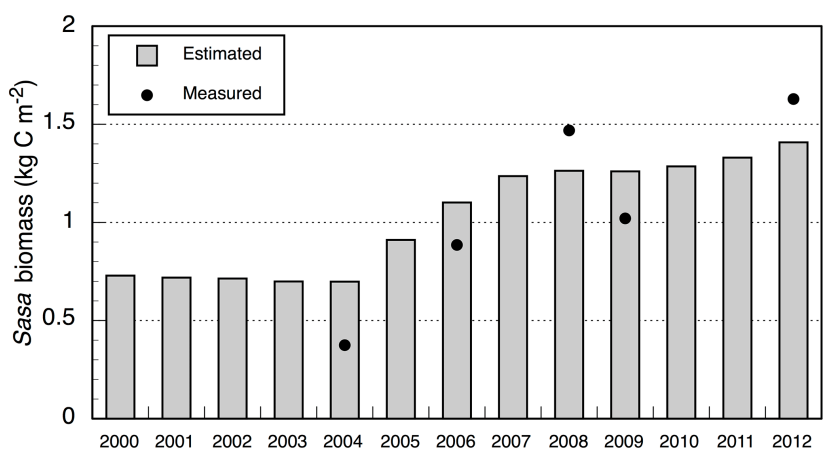

Figure 6. Interannual changes in carbon stock in dwarf bamboo (Sasa kurilensis and S. senanensis). Sasa biomass is estimated from the light transmittance.

\section{Discussion}

\subsection{Relationship between monthly mean GPP and PAR}

Figure 8 shows an anticlockwise hysteresis change in the relationship between PAR and GPP in the snow-free season. We could separate monthly data into three groups: the growing season (June-September), the leafless season (April and November), and the transitional season (May and October). In the leafless season, only Sasa could continue to carry out photosynthesis because it is an evergreen species. The greater proportion of Sasa emerged from the snowpack and generally started photosynthesis in mid-April. The Sasa was not buried under snow during November, but PAR was very small for photosynthesis. The GPP value after the disturbance was greater than that before the disturbance in the elliptical dotted lines. Because $\mathrm{LAI}_{\text {Sasa }}$ increased by a factor of 2.4 after the disturbance (Fig. 7), the GPP value was small but clearly increased. In the growing season, the GPP value after the disturbance was slightly less than that before the disturbance in the elliptical solid lines. Despite the forest being severely damaged, the GPP value decreased by only a small percentage. The value of $\mathrm{LAI}_{\text {tree }}$ reached a maximum during July or August, which was maintained until September (Mizoguchi et al., 2014b). The total LAI recovered to about $70 \%$ by 2007; nevertheless, the $\mathrm{LAI}_{\text {tree }}$ dropped by one sixth after the disturbance. The value of GPP for Sasa, which experienced a growth spurt, compensated for the GPP value by the decline in canopy trees in the growing season. Consequently, as seen in Fig. 4, the annual GPP dropped by only $6 \%$ after the disturbance. The increases in $\mathrm{LAI}_{\text {Sasa }}$ had a significant effect on GPP in the years immediately following the disturbance.

\subsection{Relationship between monthly mean $\mathrm{Re}$ and air temperature}

Figure 9 shows the exponential functions between air temperature and $\mathrm{Re}$ in the snow-free season. The value

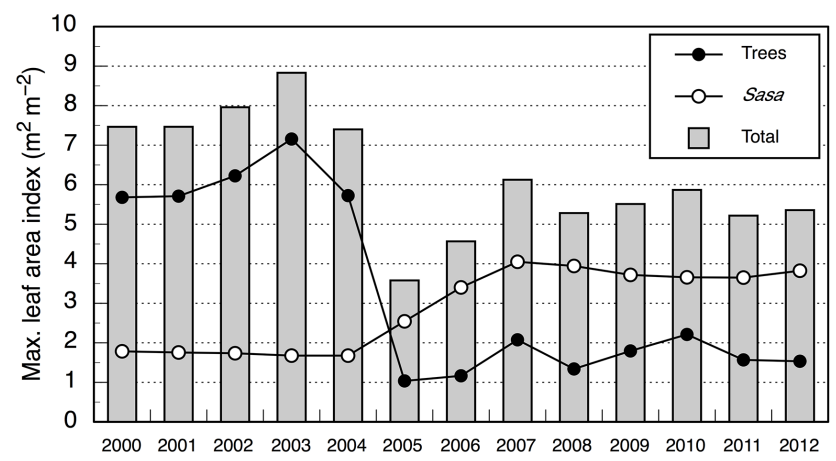

Figure 7. Interannual changes in maximum leaf area index in the canopy tree and dwarf bamboo (Sasa kurilensis and S. senanensis). Each of them is estimated from the light transmittance.

of $\mathrm{Re}$ after the disturbance at 5 and $20^{\circ} \mathrm{C}$ increased by factors of 1.50 and 1.61, as compared with that before the disturbance. The coarse-wood debris (CWD) of $4.82 \mathrm{~kg} \mathrm{Cm}^{-2}$ (41\% of the biomass before the disturbance) supplied to the forest floor resulted in a $\mathrm{CO}_{2}$ source after the disturbance. Utsugi et al. (2010) indicated that the decomposition rate of CWD is $0.04 \mathrm{yr}^{-1}$. The fallen biomass decomposed into $0.916 \mathrm{~kg} \mathrm{Cm}^{-2}$ in the first 5 years after the disturbance. Therefore, the mean decomposition rate was $183 \mathrm{~g} \mathrm{Cm}^{-2} \mathrm{yr}^{-1}$. The annual $\mathrm{Re}$ increased from $978 \mathrm{~g} \mathrm{Cm}^{-2} \mathrm{yr}^{-1}$ before the disturbance to $1359 \mathrm{~g} \mathrm{C} \mathrm{m}^{-2} \mathrm{yr}^{-1}$ in 2006. The $380 \mathrm{~g} \mathrm{C} \mathrm{m}^{-2} \mathrm{yr}^{-1}$ increase in the annual Re was 2.1 times as large as the decomposition rate of CWD. The decomposition of soil organic matter may constitute half of the increased annual Re. The forest management policy of not extracting dead trees will have a significant effect on the change in Re after the disturbance.

Because the soil surface did not freeze and the soil temperature reached nearly $0^{\circ} \mathrm{C}$ under the snow cover, most of the carbon was released as soil respiration through the snow cover. The value of Re in the snowy season agreed with that in the snow-free season at an air temperature equal to $0{ }^{\circ} \mathrm{C}$ (Fig. 9). In the snowy season, the value of Re was constant over a period of 4 months and a considerable amount of $\mathrm{Re}$ was released.

\subsection{Carbon balances before and after the disturbance}

The carbon balances within the SAP forest before and after the disturbance as estimated by the biometrical methods were integrated into Table 2 and were compared with the fluxes measured by the eddy covariance method. Net primary production (NPP) was calculated by adding together ANPP and the changes in SBM and root biomass. Autotrophic respiration (Ra) of aboveground parts and soil respiration (Rs) were estimated by using chambers (Utsugi et al., 2008; Sakata et al., 2008). The heterotrophic respiration (Rh) of CWD was estimated in Sect. 4.2. The Rh values of litter and soil decomposition were estimated by using incubation tests (T. Sakata, 


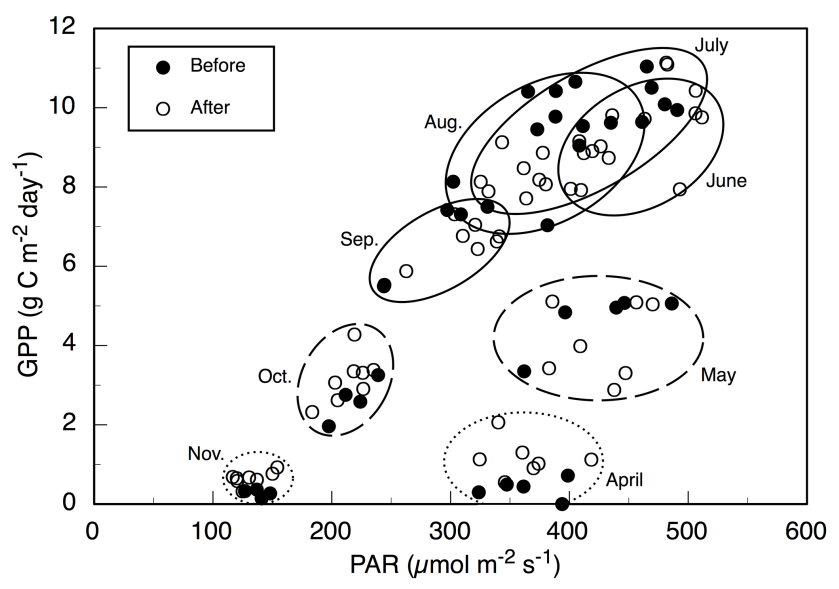

Figure 8. Relationships between monthly mean gross primary production (GPP) and monthly mean photosynthetically active radiation (PAR) in the snow-free season. Each month's data are enclosed by ellipses. Black and white circles represent monthly data before and after the disturbance, respectively. The snow-free season is separated into three periods. The elliptical solid, broken, and dotted lines indicate the growing season (June-September), transition season (May and October), and leafless season without snow (April and November), respectively.

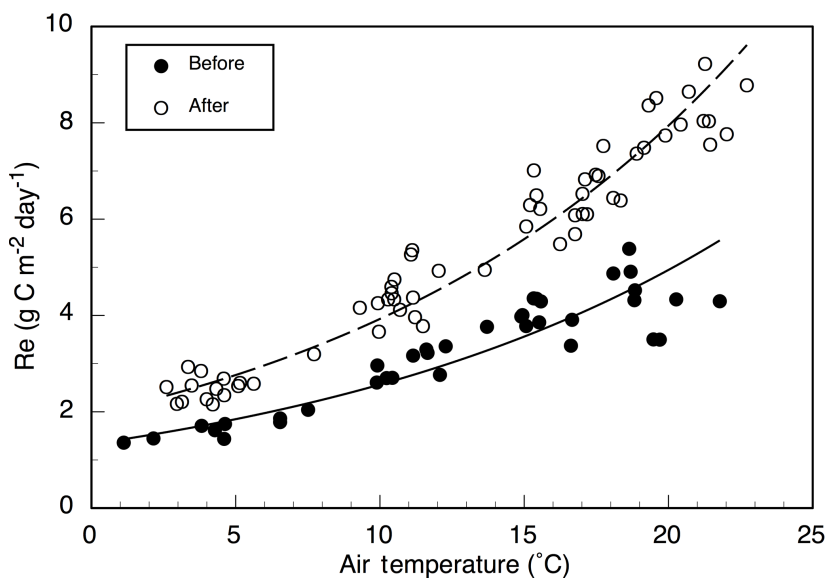

Figure 9. Relationships between monthly mean ecosystem respiration $(\mathrm{Re})$ and mean air temperature $(\mathrm{Ta})$ in the snow-free season. Black and white circles represent values before and after the disturbance, respectively. The solid line indicates the regression equation before the disturbance, i.e., $\mathrm{Re}=1.94 \times 2.02^{\mathrm{Ta} / 10}$. The broken line indicates the regression equation after the disturbance, i.e., $\operatorname{Re}=1.33 \times 1.93^{\mathrm{Ta}} / 10$

personal communication, 2010). The Ra value of root was estimated as the difference between the value of Rs and the value of Rh.

Carbon fluxes measured by the two methods were in reasonable agreement with each other. In general, the measurements by the eddy covariance method gave smaller values. However, the changes before and after the disturbance showed the same tendency. Specifically, GPP decreased by
Table 2. Carbon balances at the SAP site before and after the windthrow disturbance. Gross primary production (GPP), ecosystem respiration $(\mathrm{Re})$, and net ecosystem production (NEP) were measured by eddy covariance methods. Net primary production (NPP) was calculated by adding together the aboveground net primary production and the changes in Sasa and root biomass. Autotrophic respiration $(\mathrm{Ra})$ is composed of respirations from leaves, branches, stems, and roots. The Ra values of aboveground parts were estimated by using chambers (Utsugi et al., 2008). The Ra value of root was estimated as the difference between the soil respiration ( $\mathrm{Rs}$ ) and the heterotrophic respiration $(\mathrm{Rh})$. The $\mathrm{Rh}$ value of coarse-wood debris was estimated in the section 4.2. The $R h$ values of litter and soil decomposition were estimated by using incubation tests (T. Sakata, personal communication, 2010). The value of Rs was estimated by using chambers (Sakata et al., 2008) The periods before and after the disturbance are 2000-2003 and 2006-2008, respectively.

\begin{tabular}{lrrrr}
\hline $\begin{array}{l}\text { Component } \\
\left(\mathrm{g} \mathrm{C} \mathrm{m}^{-2} \mathrm{yr}^{-1}\right)\end{array}$ & \multicolumn{2}{c}{ Before disturbance } & \multicolumn{2}{c}{ After disturbance } \\
Biometric & Eddy cov. & Biometric & Eddy cov. \\
\hline $\mathrm{GPP}(=\mathrm{NPP}+\mathrm{Ra})^{1}$ & 1552 & 1349 & 1517 & 1293 \\
$\mathrm{NPP}$ & 678 & & 660 & \\
$\mathrm{Re}(=\mathrm{Ra}+\mathrm{Rh})^{1}$ & 1285 & 978 & 1641 & 1424 \\
$\mathrm{Ra}$ & 875 & & 858 & \\
$\mathrm{Rh}$ & 410 & & 783 & \\
$\mathrm{Rs}$ & 730 & & 984 & -131 \\
$\mathrm{NEP}(=\mathrm{NPP}-\mathrm{Rh})^{1}$ & 267 & 374 & -123 & - \\
\hline 1 Mean annual rates were measured by the eddy covariance method and were calculated \\
biometrically by the formula.
\end{tabular}

only a few percentage points, Re increased at a rate of $>$ $30 \%$, and NEP changed from a positive value to a negative value.

The Ra of the canopy trees decreased drastically, but the increased Ra of Sasa had a compensatory effect. After the disturbance, a slight reduction in Ra occurred. On the other hand, the value of $\mathrm{Rh}$ was increased by a factor of 1.9 after the disturbance. The increases in the decomposition of CWD and soil organic matter were estimated to be 183 and $190 \mathrm{~g} \mathrm{C} \mathrm{m}^{-2} \mathrm{yr}^{-1}$, respectively. Because about $80 \%$ of the fallen CWD remained in 2009, CWD continued to decompose for long periods. A steady increase in the value of the annual Re after the disturbance, as shown in Fig. 4, suggested that the decomposition rate of CWD was increasing year by year. The change in the $\mathrm{Rh}$ value after the disturbance plays an important role in the carbon balance in the forest.

Because SBM and LAI $\mathrm{Lasa}_{\text {Sa }}$ were limited by the availability of light above the undergrowth in 2008 (Figs. 6 and 7), Sasa rapidly grew during the first 3 years after the disturbance, with a maximum growth rate of $213 \mathrm{~g} \mathrm{C} \mathrm{m}^{-2} \mathrm{yr}^{-1}$, greater than the growth rate of trees shown in Fig. 5. Increases in $\mathrm{LAI}_{\text {Sasa }}$ and the light at the forest floor resulted in a compensatory slight decrease in the annual GPP. NEP values in 2006 and 2007 were constant, as shown in Fig. 4, because a remarkable growth of Sasa caused a gentle increase in $\mathrm{CO}_{2}$ release. Therefore, after $\mathrm{SBM}$ and $\mathrm{LAI}_{\text {Sasa }}$ became saturated, $\mathrm{CO}_{2}$ release increased steadily and stabilized in 2010 . Be- 
Table 3. Characteristics of the eddy covariance measurement in forest sites. Sites were selected with a focus on disturbance or management history. Some mature forest sites of a certain stand age were added.

\begin{tabular}{|c|c|c|c|c|c|c|c|c|}
\hline $\begin{array}{l}\text { Site location } \\
\text { name or symbol }\end{array}$ & $\begin{array}{l}\text { Forest } \\
\text { type }^{1}\end{array}$ & $\begin{array}{l}\text { Disturbance } \\
\text { history }\end{array}$ & Years $^{2}$ & $\begin{array}{r}\mathrm{GPP}^{3} \\
\left(\mathrm{~g} \mathrm{Cm}^{-2} \mathrm{yr}^{-1}\right)\end{array}$ & $\left(\mathrm{gCm}^{-2} \mathrm{yr}^{-1}\right)$ & $\begin{array}{r}\mathrm{NEP}^{3} \\
\left(\mathrm{gCm}^{-2} \mathrm{yr}^{-1}\right)\end{array}$ & $\mathrm{GPP} / \mathrm{Re}$ & References \\
\hline \multicolumn{9}{|l|}{ North America } \\
\hline AL, USA, Poker Flat & ENF & Fire & 5 & 299 & 229 & 70 & 1.31 & Iwata et al. (2011) \\
\hline \multirow[t]{2}{*}{ AL, USA Delta Junction } & ENF & Fire & 3,15 & 193,436 & 234,322 & $-41,114$ & $0.82,1.35$ & Welp et al. (2006) \\
\hline & ENF & Mature & ca. 80 & 499 & 426 & 70 & 1.16 & \\
\hline BC, Canada, MPB-06, -03 & ENF & Insect & $1,2,4,5$ & $439,522,432,522$ & $521,555,488,518$ & $-82,-33,-56,4$ & $0.84,0.94,0.89,0.94$ & Brown et al. (2010) \\
\hline BC, Canada, MPB-09 & ENF & Insect-harvest & $1,2,3$ & $812,954,922$ & $920,1011,974$ & $-108,-57,-52$ & $0.88,0.94,0.95$ & Mathys et al. (2013) \\
\hline BC, Canada, DF49 & ENF, & Harvest-burn & 53 & 1991 & 1737 & 254 & 1.15 & Humphreys et al. (2006) \\
\hline HDF88, HDF00 & ENF & Harvest-burn-plant & 14,3 & 1214,435 & 1347,1041 & $-133,-606$ & $0.90,0.41$ & \\
\hline SK, Canada, F98, & ENF & Fire & 6,7 & 388,456 & 385,499 & $3,-43$ & $1.01,0.91$ & Mkhabela et al. (2009) \\
\hline F89, & ENF & Fire & 15,16 & 903,902 & 787,849 & 115,53 & $1.15,1.06$ & \\
\hline F77, & ENF & Fire & 27,28 & 752,906 & 791,984 & $-39,-78$ & $0.95,0.92$ & \\
\hline OJP, & ENF & Fire-mature & 88,89 & 560,594 & 556,558 & 4,36 & $1.01,1.06$ & \\
\hline HJP02, & ENF & Harvest & 2,3 & 89,99 & 245,222 & $-155,-123$ & $0.36,0.46$ & \\
\hline HJP94, & ENF & Harvest & 10,11 & 353,410 & 360,376 & $-7,34$ & $0.98,1.09$ & \\
\hline HJP75 & ENF & Harvest & 29,30 & 544,592 & 464,513 & 80,79 & $1.17,1.15$ & \\
\hline MB, Canada, & & & & & & & & Goulden et al. (2011) \\
\hline UCI-1998, -1989, & ENF & Fire & 5,15 & 380,450 & 443,446 & $63,4.5$ & $0.86,1.01$ & \\
\hline$-1981,-1964$ & ENF & Fire & 23,40 & 710,640 & 580,478 & 131,62 & $1.23,1.34$ & \\
\hline$-1930,-1850$ & ENF & Fire & 75,154 & 630,720 & 490,667 & 140,52 & $1.29,1.08$ & \\
\hline QC, Canada, EOBS, & ENF & Fire & ca. 100 & 592 & 586 & 6 & 1.01 & Bergeron et al. (2008) \\
\hline HBSO0 & ENF & Harvest-scarf-plant & 4,5 & 274,359 & 440,483 & $-167,-124$ & $0.62,0.74$ & \\
\hline OR, USA, YS, & ENF & Harvest & 23,24 & 704,809 & 659,696 & 45,113 & $1.07,1.16$ & Schwarz et al. (2004) \\
\hline MS & ENF & Harvest-mature & ca. 90 & 1360 & 989 & 371 & 1.38 & \\
\hline WI, USA, Willow Creek & DBF & Insect & $0,1,2$ & $1099,898,1202$ & $776,821,778$ & $323,77,422$ & $1.42,1.09,1.54$ & Cook et al. (2008) \\
\hline WI, USA, MHW, & DBF & Mature & 65 & 1047 & 387 & 655 & 2.71 & Noormets et al. (2007) \\
\hline MRP, & ENF & Plant-thin-mature & 63 & 1153 & 514 & 648 & 2.24 & \\
\hline $\mathrm{PB}$ & ENF & Fire & 12 & 673 & 470 & 195 & 1.43 & \\
\hline YRP, & ENF & Harvest & 8 & 1059 & 739 & 313 & 1.43 & \\
\hline YHW & DBF & Harvest & 3 & 697 & 827 & -128 & 0.84 & \\
\hline WI, USA, Willow Creek & DBF & mature & ca. 70 & 1149 & 686 & 464 & 1.68 & Desai et al. (2005) \\
\hline MI, USA, Sylvania & DBF & Mature & $>300$ & 1034 & 924 & 110 & 1.12 & Desai et al. (2005) \\
\hline MI, USA, UMBS & MXF & Harvest-burn & 85 & 1400 & 1240 & 160 & 1.13 & Gough et al. (2008) \\
\hline OH, USA, Toledo & $\mathrm{DBF}$ & Mature & 45 & 1148 & 845 & 303 & 1.36 & Noormets et al. (2008) \\
\hline MA, USA, Harvard Forest & MXF & Windthrow-mature & $75-110$ & 1400 & 1150 & 242 & 1.22 & Urbanski et al. (2007) \\
\hline \multirow[t]{3}{*}{ NJ, USA, Pine Barrens } & MXF & Insect & 0,1 & 1153,491 & 1007,785 & 146,294 & $1.14,0.63$ & Clark et al. (2010) \\
\hline & MXF & Insect & $0,1,2$ & $877,804,702$ & $740,907,831$ & $137,-103,-129$ & $1.19,0.88,0.84$ & \\
\hline & MXF & Insect & 0,1 & 1370,1170 & 1187,1153 & 183,17 & $1.15,1.01$ & \\
\hline NC, USA, Duke Forest & ENF & Plant & 17 & 1808 & 1203 & 605 & 1.50 & Lai et al. (2002) \\
\hline \multirow[t]{3}{*}{ AZ, USA, Flagstaff } & MXF & Mature & $>100$ & 879 & 786 & 110 & 1.12 & Dore et al. (2010) \\
\hline & ENF & Thin & 0,1 & 909,826 & 811,902 & $118,-51$ & $1.12,0.92$ & \\
\hline & GS & Fire & 10,11 & 372,401 & 480,453 & $-109,-45$ & $0.78,0.88$ & \\
\hline CA, USA, Blodgett & ENF & Plant-thin & $0,1-3$ & $1462,1260-1777$ & $1261,1254-1604$ & $201,-13-172$ & $1.16,0.99-1.11$ & Misson et al. (2005) \\
\hline \multirow[t]{3}{*}{ FL, USA, Gainesville } & ENF & Harvest-plant & 1,2 & 705,1504 & 1974,2386 & $-1269,-882$ & $0.36,0.63$ & Clark et al. (2004) \\
\hline & ENF & Harvest-plant & 10,11 & 2922,2605 & 2346,2002 & 576,603 & $1.25,1.30$ & \\
\hline & ENF & Harvest-plant & 24,25 & 2695,2517 & 1956,1907 & 741,610 & $1.38,1.32$ & \\
\hline \multicolumn{9}{|l|}{ Europe } \\
\hline European Russia, Tver & MXF & Windthrow & 2 & 109 & 218 & -109 & 0.50 & Knohl et al. (2002) \\
\hline Hyytiälä, Finland, SMEAR II & ENF & Plant & 36 & 949 & 720 & 228 & 1.32 & Markkanen et al. (2001) \\
\hline Central Sweden, Norunda & ENF & Harvest-drain & $50-100$ & 1075 & 1127 & -52 & 0.95 & Lagergren et al. (2008) \\
\hline Zealand, Denmark, Sor $\varnothing$ & DBF & Mature & 80 & 1303 & 1120 & 184 & 1.16 & Pilegaard et al. (2001) \\
\hline Oxford, UK, Wytham Woods & DBF & Coppice-mature & 40 & 2110 & 1980 & 130 & 1.07 & Thomas et al. (2011) \\
\hline \multirow[t]{2}{*}{ UK } & ENF & Harvest-mature & 41 & 1970 & 1385 & 496 & 1.42 & Kowalski et al. (2004) \\
\hline & ENF & Harvest-plant & 3 & 988 & 1100 & -112 & 0.90 & \\
\hline Eisenach, Germany, Hainich & DBF & Coppice-mature & ca. 250 & 1560 & 1068 & 492 & 1.46 & Knohl et al. (2003) \\
\hline Brasschaat, Belgium, De Inslag & MXF & Plant-thin & 71 & 1234 & 1326 & -91 & 0.93 & Carrara et al. (2004) \\
\hline Hesse, France, FR02 & DBF & Mature-thin & 30 & 1128 & 891 & 238 & 1.27 & Granier et al. (2000) \\
\hline Bordeaux, France, Bray & ENF & Plant & 28 & 2255 & 1680 & 575 & 1.34 & Berbigier et al. (2001) \\
\hline Les Landes, France, Bilos & ENF & Harvest & 2 & 727 & 996 & 290 & 0.73 & Kowalski et al. (2003) \\
\hline \multirow[t]{2}{*}{ Central Italy } & DBF & Coppice-mature & 10 & 1600 & 1160 & 381 & 1.38 & Kowalski et al. (2004) \\
\hline & DBF & Coppice & 2 & 1420 & 2220 & -427 & 0.64 & \\
\hline Asia & & & & & & & & \\
\hline Mongonmorit, Mongolia, SKT & DNF & Thin-fire-insect & $70-150$ & 525 & 440 & 85 & 1.19 & Li et al. (2005) \\
\hline Gwangneung, Korea, GDK & DBF & Mature & $80-200$ & 835 & 746 & 87 & 1.12 & Kwon et al. (2009) \\
\hline Teshio, Japan, TSE & MXF & Harvest-plant & $0,1-9$ & $1439,481-1238$ & $1395,1035-1229$ & $44,-569-52$ & $1.03,0.46-1.05$ & Aguilos et al. (2014) \\
\hline Sapporo, Japan, SAP & DBF & Windthrow & $0,2-8$ & $1349,1214-1460$ & $975,1360-1741$ & $374,-82$ to -365 & $1.38,0.77-0.94$ & This study \\
\hline Tomakomai, Japan, TMK & DNF & Windthrow-plant & 48 & 1673 & 1461 & 212 & 1.15 & Hirata et al. (2007) \\
\hline Appi, Japan, API & DBF & Harvest-mature & ca. 90 & 1177 & 899 & 278 & 1.31 & Yasuda et al. (2012) \\
\hline Kawagoe, Japan, KWG & DBF & Coppice-insect & ca. 25 & 1453 & 1190 & 263 & 1.22 & Yasuda et al. (1998) \\
\hline Fujiyoshida, Japan, FJY & ENF & Coppice-mature & ca. 90 & 1802 & 1413 & 388 & 1.28 & Mizoguchi et al. (2012) \\
\hline Takayama, Japan, TKY & DBF & Mature & ca. 50 & 978 & 742 & 237 & 1.32 & Saigusa et al. (2005) \\
\hline Kiryu, Japan, KEW & ENF & Plant & 43 & 1539 & 1060 & 523 & 1.45 & Takanashi et al. (2005) \\
\hline Pasoh, Malaysia, PSO & $\mathrm{EBF}$ & Mature & $>100$ & 3243 & 3119 & 124 & 1.04 & Kosugi et al. (2008) \\
\hline Kalimantan, Indonesia, DB & BS & Drain-fire & $2-6$ & $1071-1428$ & $1662-1871$ & -318 to -591 & $0.64-0.82$ & Hirano et al. (2012) \\
\hline
\end{tabular}




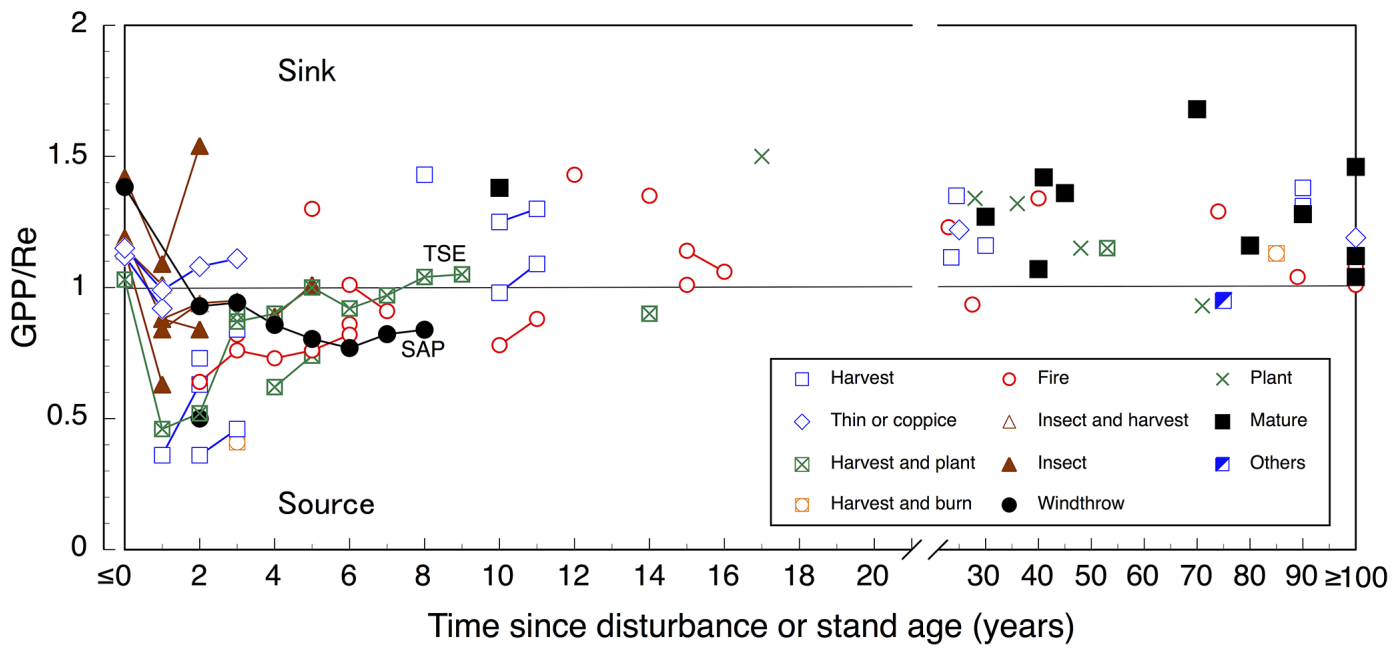

Figure 10. The carbon uptake efficiency $(\mathrm{GPP} / \mathrm{Re})$ in forest with years since last disturbance in the forest or stand age for the mature forest. The GPP / Re with years $\leq 0$ (data before disturbance) is plotted on the left margin. Similarly, the GPP/Re with years older than or equal to 100 is plotted on the right margin. Data older than 20 years are averaged. In particular, data of the TSE site (Aguilos et al., 2014) and SAP site (the present study) are indicated. At these two sites, the measurements include periods both before and after the disturbance and were taken for over 10 years.

cause the recruitment of trees increased in 2012 (Fig. 5b), $\mathrm{CO}_{2}$ release decreased slightly under forest restoration.

\subsection{Comparison with other disturbed and mature forest ecosystems}

The $\mathrm{CO}_{2}$ fluxes measured by the eddy covariance method are summarized in Table 3. Data at 75 sites were selected with a focus on the history of a disturbed forest and a stand age of a mature forest. The disturbances included forest fires, insect infestation, windthrow events, harvest, tree thinning, and plantation. Some mature forests with an identified stand age were also included. The measurements that included periods both before and after disturbances were taken at eight sites. Only two sites (sites TSE and SAP) included measurements from a period longer than 10 years. Because the carbon budget changed drastically in the years after the disturbance, it is very important to maintain measurements over a long term.

The calculation of carbon uptake efficiency (GPP / Re) in the forest is shown in Table 3 and plotted with years since the last disturbance for the disturbed forest or stand age for the mature forest in Fig. 10. The GPP / Re with years $\leq 0$ (data before disturbance) is plotted on the left margin. Similarly, the GPP / Re with years greater than or equal to 100 is plotted on the right margin. Because the GPP / Re changed with the type and intensity of the disturbance, it was scattered around the line equal to 1 . The GPP / Re plotted on the left margin was greater than 1 (carbon sink), and all values were derived from the mature forest before the disturbance. The mature or older forests are also expressed on the right margin in Fig. 10. The GPP / Re for the forests was $>1$ except for Norunda, De Inslag, and F77 listed in Table 3. Norunda, in central Sweden, has been shown to have an unusual carbon balance (Lagergren et al., 2008). Valentini et al. (2000) pointed out that the carbon is being lost in Norunda as a result of past soil drainage, plowing, and fertilization. De Inslag in Belgium was losing carbon as a result of intensive thinning during the 1980s (Carrara et al., 2003). The cause of the carbon source in F77, Saskatchewan, Canada, where there was a burnt forest as reported by Mkhabela et al. (2009), is unknown. As show in Fig. 10, $\mathrm{CO}_{2}$ uptake occurred in the forest ecosystem after a long period and in most of the mature or older forests. For example, Knohl et al. (2003) showed a large $\mathrm{CO}_{2}$ uptake by an unmanaged 250-year-old forest in central Germany. The GPP / Re in this case was 1.46, demonstrating a considerable carbon sink.

The GPP / Re after the disturbance changed rapidly and widely, as shown in Fig. 10. At most disturbed sites, the greatest decreases appeared just after the disturbance, whereas the GPP / Re dropped gently at the SAP site. The management procedure adopted after the disturbance at the SAP site, where all dead trees remained on site, played an important role in the distribution of decomposable organic matter. An increase in Rh from CWD and a remarkable growth of Sasa, as mentioned above, will surely affect the carbon balance. We compared the GPP / Re at the SAP site with that at the TSE site, where trees were clear-cut and half the biomass was removed as logs (Aguilos et al., 2014). The ecosystem carbon compensation point at which carbon balance changed from a carbon source to a sink at the TSE site was after 8 years compared with over 10 years at the SAP site. The greater residual CWD at the SAP site resulted in later restoration. Consequently, the amount of the residues plays an important role in the disturbance chronosequences. 
Figure 10 demonstrates that the GPP / Re crosses the compensation point after approximately 20 years at all disturbed sites. We estimate that the GPP / Re crosses the compensation point after approximately 15 years at the SAP site.

\section{Conclusions}

We performed measurements of the carbon balance over a 4-year period before the windthrow disturbance and over 8 years thereafter in a deciduous broadleaf forest in Hokkaido, Japan. Before the disturbance, the forest fulfilled the role of an evident carbon sink, and it changed to a carbon source after the disturbance. Because of increased light intensity at the forest floor after the disturbance, the photosynthesis of Sasa increased rapidly, ultimately contributing to the total GPP. The annual GPP only decreased by $6 \%$ just after the disturbance. On the other hand, the annual Re increased by $39 \%$, mainly because of the decomposition of residual CWD. A steady increase in the annual Re after the disturbance suggested that the decomposition rate of the CWD was increasing year after year. Consequently, the carbon balance after the disturbance was controlled by the new growth and the decomposition of residues.

We characterized the SAP site by the impact caused by the windthrow and the subsequent forest management adapted after the disturbance. The observations of a forest damaged by windthrow are novel. In particular, the measurements reported here include periods before and after the disturbance. The forest management, which resulted in the dead stands remaining at the study site, strongly affected the carbon budget over the years. When comparing the carbon uptake efficiency at the SAP site with that at others, including sites with various kinds of disturbances, we emphasized the importance to the carbon budget of forest management as well as the disturbance type.

Author contributions. K. Yamanoi and Y. Mizoguchi designed and carried out the meteorological experiments. H. Utsugi designed the biometrical experiments, and all authors carried them out. K. Yamanoi prepared the manuscript with contributions from coauthors.

Acknowledgements. This study was supported in part by Research Revolution 2002 (FY 2002-2007) and Grants-in-Aid for Scientific Research (19380095 and 19587 019) from the Japanese Ministry of Education, Culture, Sports, Science and Technology; the Project Research Fund (Environment Research: FY 2006-2014) from the Japanese Ministry of Agriculture, Forestry and Fisheries; and the Global Environment Research Account (FY 2007-2014) from the Japanese Ministry of the Environment. We are grateful to T. Sakata for personal communication regarding soil carbon and to S. Kuramoto for offering litterfall data. We also wish to thank our colleagues, K. Kitamura, Y. Ohtani, Y. Nakai, S. Suzuki, S. Yuta, H. Sugata, and H. Yamamoto, for their research assistance.
Edited by: A. Neftel

\section{References}

Aguilos, M., Takagi, K., Liang, N., Ueyama, M., Fukuzawa, K., Nomura, M., Kishida, O., Fukazawa, T., Takahashi, H., Kotsuka, C., Sakai, R., Ito, K., Watanabe, Y., Fujinuma, Y., Takahashi, Y., Murayama, T., Saigusa, N., and Sasa, K.: Dynamics of ecosystem carbon balance recovering from a clear-cutting in a cooltemperate forest, Agr. Forest Meteorol., 197, 26-39, 2014.

Amiro, B. D., Barr, A. G., Barr, J. G., Black, T. A., Bracho, R., Brown, M., Chen, J., Clark, K. L., Davis, K. J., Desai, A. R., Dore, S., Engel, V., Fuentes, J. D., Goldstein, A. H., Goulden, M. L., Kolb, T. E., Lavigne, M. B., Law, B. E., Margolis, H. A., Martin, T., McCaughey, J. H., Misson, L., Montes-Helu, M., Noormets, A., Randerson, J. T., Starr, G., and Xiao, J.: Ecosystem carbon dioxide fluxes after disturbance in forests of North America, J. Geophys. Res., 115, G00K02, doi:10.1029/2010JG001390, 2010.

Berbigier, P., Bonnefond, J.-M., and Mellmann, P.: $\mathrm{CO}_{2}$ and water vapour fluxes for 2 years above Euroflux forest site, Agr. Forest Meteorol., 108, 181-197, 2001.

Bergeron, O., Margolis, H. A., Coursolle, C., and Giasson, M.-A.: How does forest harvest influence carbon dioxide fluxes of black spruce ecosystems in eastern North America?, Agr. Forest Meteorol., 148, 537-548, 2008.

Brown, M., Black, T. A., Nesic, Z., Foord, V. N., Spittlehouse, D. L., Fredeen, A. L., Grant, N. J., Burton, P. J., and Trofymow, J. A.: Impact of mountain pine beetle on the net ecosystem production of lodgepole pine stands in British Columbia, Agr. Forest Meteorol., 150, 254-264, 2010.

Carrara, A., Kowalski, A. S., Neirynck, J., Janssens, I. A., Yuste, J. C., and Ceulemans, R.: Net ecosystem $\mathrm{CO}_{2}$ exchange of mixed forest in Belgium over 5 years, Agr. Forest Meteorol., 119, 209-227, 2003.

Carrara, A., Janssens, I. A., Yuste, J. C., and Ceulemans, R.: Seasonal changes in photosynthesis, respiration and NEE of a mixed temperate forest, Agr. Forest Meteorol., 126, 15-31, 2004.

Chambers, J. Q., Fisher, J. I., Zeng, H., Chapman, E. L., Baker, D. B., and Hurtt, G. C.: Hurricane Katrina's carbon footprint on US gulf coast forests, Science, 318, p. 1107, doi:10.1126/science.1148913, 2007.

Clark, D. A., Brown, S., Kicklighter, D. W., Chambers, J. Q., Thomlinson, J. R., and Ni, J.: Net primary production in forests: concepts and field methods, Ecol. Appl., 11, 356-370, 2001.

Clark, K. L., Gholz, H. L., and Castro, M. S.: Carbon dynamics along a chronosequence of slash pine plantations in north Florida, Ecol. Appl., 14, 1154-1171, 2004.

Clark, K. L., Skowronski, N., and Hom, J.: Invasive insects impact forest carbon dynamics, Glob. Change Biol., 16, 88-101, 2010.

Cook, B. D., Bolstad, P. V., Martin, J. G., Heinsch, F. A., Davis, K. J., Wang, W., Desai, A. R., and Teclaw, R. M.: Using light-use and production efficiency models to predict photosynthesis and net carbon exchange during forest canopy disturbance, Ecosystems, 11, 26-44, 2008.

Desai, A. R., Bolstad, P. V., Cook, B. D., Davis, K. J., and Carey, E. V.: Comparing net ecosystem exchange of carbon diox- 
ide between an old-growth and mature forest in the upper Midwest, USA, Agr. Forest Meteorol., 128, 33-55, 2005.

Dore, S., Kolb, T. E., Montes-Helu, M., Eckert, S. E., Sullivan, B. W., Hungate, B. A., Kaye, J. P., Hart, S. C., Koch, G. W., and Finkral, A.: Carbon and water fluxes from ponderosa pine forests disturbed by wildfire and thinning, Ecol. Appl., 20, 663683,2010

Foken, T. and Wichura, B.: Tools for quality assessment of surfacebased flux measurements, Agr. Forest Meteorol., 78, 83-105, 1996.

Goetz, S. J., Bond-Lamberty, B., Law, B. E., Hicke, J. A., Huang, C., Houghton, R. A., McNulty, S., O'Halloran, T., Harmon, M., Meddens, A. J. H., Pfeifer, E. M., Mildrexler, D., and Kasischke, E. S.: Observations and assessment of forest carbon dynamics following disturbance in North America, J. Geophys. Res., 117, G02022, doi:10.1029/2011JG001733, 2012.

Gough, C. M., Vogel, C. S., Schmid, H. P., and Curtis, P. S.: Controls on annual forest carbon storage: lessons from the past and predictions for the future, Bioscience, 58, 609-622, 2008.

Goulden, M. L., McMillan, A. M. S., Winston, G. C., Rocha, A. V., Manies, K. L., Harden, J. W., and Pond-Lamberty, B. P.: Patterns of NPP, GPP, respiration, and NEP during boreal forest succession, Glob. Change Biol., 17, 855-871, 2011.

Granier, A., Ceschia, E., Damesin, C., Dufrene, E., Epron, D., Gross, P., Lebaube, S., Le Dantec, V., Le Goff, N., Lemoine, D., Lucot, E., Ottorini, J. M., Pontailler, J. Y., and Saugier, B.: The carbon balance of a young Beech forest, Funct. Ecol., 14, 312325,2000

Hignett, P.: Corrections to temperature measurements with a sonic anemometer, Bound.-Lay. Meteorol., 61, 175-187, 1992.

Hirano, T., Segah, H., Kusin, K., Limin, S., Takahashi, H., and Osaki, M.: Effects of disturbances on the carbon balance of tropical peat swamp forests, Glob. Change Biol., 18, 3410-3422, 2012.

Hirata, R., Hirano, T., Saigusa, N., Fujinuma, Y., Inukai, K., Kitamori, Y., Takahashi, Y., and Yamamoto, S.: Seasonal and interannual variations in carbon dioxide exchange of a temperate larch forest, Agr. Forest Meteorol., 147, 110-124, 2007.

Hirata, R., Saigusa, N., Yamamoto, S., Ohtani, Y., Ide, R., Asanuma, J., Gamo, M., Hirano, T., Kondo, H., Kosugi, Y., Li, S.-G., Nakai, Y., Takagi, K., Tani, M., and Wang, H.: Spatial distribution of carbon balance in forest ecosystems across East Asia, Agr. Forest Meteorol., 148, 761-775, 2008.

Hokkaido Forestry Research Institute: Flash report on wind damage caused by Typhoon No. 18 in 2004, Kohshunai Seasonal Rep., 137, 1-12, 2004 (in Japanese).

Humphreys, E. R., Black, T. A., Morgenstern, K., Cai, T., Drewitt, G. B., Nesic, Z., and Trofymow, J. A.: Carbon dioxide fluxes in coastal Douglas-fir stands at different stages of development after clearcut harvesting, Agr. Forest Meteorol., 140, 6-22, 2006.

IPCC: Large-scale storm systems, in: Climate Change 2013: The Physical Science Basis. Contribution of Working Group I to the Fifth Assessment Report of the Intergovernmental Panel on Climate Change, Cambridge University Press, Cambridge, United Kingdom and New York, NY, USA, 1248-1253, 2013.

Ito, A.: Evaluation of the impacts of defoliation by tropical cyclones on a Japanese forest's carbon budget using flux data and a process-based model, J. Geophys. Res., 115, G04013, doi:10.1029/2010JG001314, 2010.
Ishizuka, S., Sakata, T., Sawata, S., Ikeda, S., Takenaka, C., Tamai, N., Sakai, H., Shimizu, T., Kan-na, K., Onodera, S., Tanaka, N., and Takahashi, M.: High potential for increase in $\mathrm{CO}_{2}$ flux from forest soil surface due to global warming in cooler areas of Japan, Ann. For. Sci., 63, 537-546, 2006.

Iwata, H., Ueyama, M., Harazono, Y., Tsuyuzaki, S., Kondo, M., and Uchida, M.: Quick recovery of carbon dioxide exchanges in a burned black spruce forest in interior Alaska, Sola, 7, 105-108, 2011.

Kaimal, J. C. and Gaynor, J. E.: Another look at sonic thermometry, Bound.-Lay. Meteorol., 56, 401-410, 1991.

Kitamura, K., Nakai, Y., Suzuki, S., Ohtani, Y., Yamanoi, K., and Sakamoto, T.: Interannual variability of net ecosystem production for a broadleaf deciduous forest in Sapporo, northern Japan, J. Forest Res., 17, 323-332, 2012.

Knohl, A., Kolle, O., Minayeva, T. Y., Milyukova, I. M., Vygodskaya, N, N., Foken, T., and Schulze, E.-D.: Carbon dioxide exchange of a Russian boreal forest after disturbance by wind throw, Glob. Change Biol., 8, 231-246, 2002.

Knohl, A., Schulze, E.-D., Kolle, O., and Buchmann, N.: Large carbon uptake by an unmanaged 250-year-old deciduous forest in Central Germany, Agr. Forest Meteorol., 118, 151-167, 2003.

Kosugi, Y., Takanashi, S., Ohkubo, S., Matsuo, N., Tani, M., Mitani, T., Tsutsumi, D., and Nik, A. R.: $\mathrm{CO}_{2}$ exchange of a tropical rainforest at Pasoh in Peninsular Malaysia, Agr. Forest Meteorol., 148, 439-452, 2008.

Kowalski, A. S., Sartore, M., Burlett, R., Berbigier, P., and Loustau, D.: The annual carbon budget of a French pine forest (Pinus pinaster) following harvest, Glob. Change Biol., 9, 1051-1065, 2003.

Kowalski, A. S., Loustau, D., Berbigier, P., Manca, G., Tedeschi, V., Borghetti, M., Valentini, R., Kolari, P., Berninger, F., Rannik, Ü., Hari, P., Rayment, M., Mencuccini, M., Moncrieff, J., and Grace, J.: Paired comparisons of carbon exchange between undisturbed and regenerating stands in four managed forests in Europe, Glob. Change Biol., 10, 1707-1723, 2004.

Kwon, H., Park, T.-Y., Hong, J., Lim, J.-H., and Kim, J.: Seasonality of net ecosystem carbon exchange in two major plant function types in Korea, Asia - Pacific, J. Atmos. Sci., 45, 149-163, 2009.

Körner, C.: Slow in, rapid out: carbon flux studies and Kyoto targets, Science, 300, 1242-1243, 2003.

Lagergren, F., Lindroth, A., Dellwik, E., Ibrom, A., Lankreijer, H., Launiainen, S., Mölder, M., Kolari, P., Pilegaard, K., and Vesala, T.: Biophysical controls on $\mathrm{CO}_{2}$ fluxes of three northern forests based on long-term eddy covariance data, Tellus B, 60, 143-152, 2008.

Lai, C.-T., Katul, G., Butnor, J., Ellsworth, D., and Oren, R.: Modelling night-time ecosystem respiration by a constrained source optimization method, Glob. Change Biol., 8, 124-141, 2002.

Lamlom, S. H. and Savidge, R. A.: A reassessment of carbon content in wood: variation within and between 41 North American species, Biomass Bioenergy, 25, 381-388, 2003.

Law, B. E., Falge, E., Gu, L., Baldocchi, D. D., Bakwin, P., Berbigier, P., Davis, K., Dolman, A. J., Falk, M., Fuentes, J. D., Goldstein, A., Granier, A., Grelle, A., Hollinger, D., Janssens, I. A., Jarvis, P., Jensen, N. O., Katul, G., Mahli, Y., Matteucci, G., Meyers, T., Monson, R., Munger, W., Oechel, W., Olson, R., Pilegaard, K., Paw U, K. T., Thorgeirsson, H., Valentini, R., Verma, S., Vesala, T., Wilson, K., and 
Wofsy, S.: Environmental controls over carbon dioxide and water vapor exchange of terrestrial vegetation, Agr. Forest Meteorol., 113, 97-120, 2002.

Leuning, R. and Moncrieff, J.: Eddy-covariance $\mathrm{CO}_{2}$ flux measurements using open- and closed-path $\mathrm{CO}_{2}$ analysers: corrections for analyser water vapour sensitivity and damping of fluctuations in air sampling tubes, Bound.-Lay. Meteorol., 53, 63-76, 1990.

Li, S.-G., Asanuma, J., Kotani, A., Eugster, W., Davaa, G., Oyunbaatar, D., and Sugita, M.: Year-round measurements of net ecosystem $\mathrm{CO}_{2}$ flux over a montane larch forest in Mongolia, J. Geophys. Res., 110, D09303, doi:10.1029/2004JD005453, 2005.

Lindroth, A., Lagergren, F., Grelle, A., Klemedtsson, L., Langvall, O., Weslien, P., and Tuulik, J.: Storms can cause Europewide reduction in forest carbon sink, Glob. Change Biol., 15, 346-355, 2009.

Magnani, F., Mencuccini, M., Borghetti, M., Berbigier, P., Berninger, F., Delzon, S., Grelle, A., Hari, P., Jarvis, P. G., Kolari, P., Kowalski, A. S., Lankreijer, H., Law, B. E., Lindroth, A., Loustau, D., Manca, G., Moncrieff, J. B., Rayment, M., Tedeschi, V., Valentini, R., and Grace, J.: The human footprint in the carbon cycle of temperate and boreal forests, Nature, 447, 848-850, 2007.

Markkanen, T., Rannik, Ü., Keronen, P., Suni, T., and Vesala, T.: Eddy covariance fluxes over a boreal Scots pine forest, Boreal Environ. Res., 6, 65-78, 2001.

Massman, W. J. and Lee, X.: Eddy covariance flux corrections and uncertainties in long-term studies of carbon and energy exchanges, Agr. Forest Meteorol., 113, 121-144, 2002.

Mathys, A., Black, T. A., Nesic, Z., Nishio, G., Brown, M., Spittlehouse, D. L., Fredeen, A. L., Bowler, R., Jassal, R. S., Grant, N. J., Burton, P. J., Trofymow, J. A., and Meyer, G.: Carbon balance of a partially harvested mixed conifer forest following mountain pine beetle attack and its comparison to a clear-cut, Biogeosciences, 10, 5451-5463, doi:10.5194/bg-10-5451-2013, 2013.

McMillen, R. T.: An eddy correlation technique with extended applicability to non-simple terrain, Bound.-Lay. Meteorol., 43, 231-245, 1988.

Misson, L., Tang, J., Xu, M., McKay, M., and Goldstein, A.: Influences of recovery from clear-cut, climate variability, and thinning on the carbon balance of a young ponderosa pine plantation, Agr. Forest Meteorol., 130, 207-222, 2005.

Mizoguchi, Y., Ohtani, Y., Takanashi, S., Iwata, H., Yasuda, Y., and Nakai, Y.: Seasonal and interannual variation in net ecosystem production of an evergreen needleleaf forest in Japan, J. Forest Res., 17, 283-295, 2012.

Mizoguchi, Y., Yamanoi, K., Kitamura, K., Nakai, Y., and Suzuki, S.: Meteorological observations at the Sapporo forest meteorology research site from 1999 to 2008, Hokkaido, Japan, Bull. For. Forest Prod. Res. Inst., 13, 193-206, 2014a (in Japanese with English summary).

Mizoguchi, Y., Yamanoi, K., Utsugi, H., and Tobita, H.: Photosynthesis active radiation at Sapporo forest meteorology research site after a typhoon disturbance, Bor. For. Res., 62, 89-90, 2014b (in Japanese).

Mkhabela, M. S., Amiro, B. D., Barr, A. G., Black, T. A., Hawthorne, I., Kidston, J., McCaughey, J. H., Orchansky, A. L., Nesic, Z., Sass, A., Shashkov, A., and Zha, T.: Comparison of carbon dynamics and water use efficiency following fire and har- vesting in Canadian boreal forests, Agr. Forest Meteorol., 149, 783-794, 2009.

Nakai, Y., Ohtani, Y., and Yamanoi, K.: Damage by typhoon 200418 at Sapporo-site, FFPRI Flux Net, AsiaFlux Newsletter, 12, 12 13, 2004.

Nilsson, C., Stjernquist, I., Bärring, L., Schlyter, P., Jönsson, A. M., and Samuelsson, H.: Recorded storm damage in Swedish forests 1901-2000, Forest Ecol. Manag., 199, 165-173, 2004.

Noormets, A., Chen, J., and Crow, T. R.: Age-dependent changes in ecosystem carbon fluxes in managed forests in northern Wisconsin, USA, Ecosystems, 10, 187-203, 2007.

Noormets, A., McNulty, S. G., DeForest, J. L., Sun, G., Li, G., and Chen, J.: Drought during canopy development has lasting effect on annual carbon balance in a deciduous temperate forest, New Phytol., 179, 818-828, 2008.

Ohtani, Y., Mizoguchi, Y., Watanabe, T., Yasuda, Y., and Okano, M.: Seasonal change of $\mathrm{CO}_{2}$ flux above an evergreen needle leaf forest in temperate region, Fujiyoshida, Japan, in: Proceedings of International Workshop for Advanced Flux Network and Flux Evaluation, Sapporo, Japan, 27-29 September 2000, 129-132, 2001.

Oshima, Y.: Ecological studies of Sasa communities, I. Productive structure of some of the Sasa communities in Japan, Bot. Mag. Tokyo, 74, 199-210, 1961a.

Oshima, Y.: Ecological studies of Sasa communities I I. Seasonal Variations of Productive Structure and annual net production in Sasa communities, Bot. Mag. Tokyo, 74, 280-290, 1961 b.

Pilegaard, K., Hummelshøj, P., Jensen, N. O., and Chen, Z.: Two years of continuous $\mathrm{CO}_{2}$ eddy-flux measurements over a Danish beech forest, Agr. Forest Meteorol., 107, 29-41, 2001.

Saigusa, N., Yamanoto, S., Murayama, S., and Kondo, H.: Interannual variability of carbon budget components in an AsiaFlux forest site estimated by long-term flux measurements, Agr. Forest Meteorol., 134, 4-16, 2005.

Sakata, T., Utsugi, H., Sakai, H., Ishizuka, S., and Tanaka, N.: Estimation of $\mathrm{CO}_{2}$ emission from the soil in a deciduous broadleaved forest at the suburb in Sapporo city - Comparison between soil respiration before and after the typhoon damage in 2004, Trans. Mtg. Hokkaido Br. Jpn. For. Soc., 56, 91-93, 2008 (in Japanese).

Sakata, T., Utsugi, H., and Aizawa, S.: Soil $\mathrm{CO}_{2}$ dynamics in deciduous forest of northern Japan - seasonal fluctuation of $\mathrm{CO}_{2}$ efflux was estimated from the concentration distribution, Trans. Mtg. Hokkaido Br. Jpn. For. Soc., 58, 79-81, 2010 (in Japanese)

Sano, T., Hirano, T., Liang, N., Hirata, R., and Fujinuma, Y.: Carbon dioxide exchange of a larch forest after a typhoon disturbance, Forest Ecol. Manag., 260, 2214-2223, 2010.

Schulze, E.-D.: Biological control of the terrestrial carbon sink, Biogeosciences, 3, 147-166, doi:10.5194/bg-3-147-2006, 2006.

Schulze, E.-D., Lloyd, J., Kelliher, F. M., Wirth, C., Rebmann, C., Lühker, B., Mund, M., Knohl, A., Milyukova, I. M., Schulze, W., Ziegler, W., Varlagin, A. B., Sogachev, A. F., Valentini, R., Dore, S., Grigoriev, S., Kolle, O., Panfyorov, M. I., Tchebakova, N., and Vygodskaya, N.: Productivity of forests in the Eurosiberian boreal region and their potential to act as a carbon sink - a synthesis, Glob. Change Biol., 5, 703-722, 1999.

Schwarz, P. A., Law, B. E., Williams, M., Irvine, J., Kurpius, M., and Moore, D.: Climatic versus biotic constraints on carbon and water fluxes in seasonally drought-affected pon- 
derosa pine ecosystems, Global Biogeochem. Cy., 18, GB4007, doi:10.1029/2004GB002234, 2004.

Smithwick, E. A. H., Harmon, M. E., Remillard, S. M., Acker, S. A., and Franklin, J. F.: Potential upper bounds of carbon stores in forests of the Pacific northwest, Ecol. Appl., 12, 1303-1317, 2002

Takahashi, M., Utsugi, H., Ishibashi, S., and Takao, G.: Forest transition after typhoon damage using LIDAR data, Trans. Mtg. Hokkaido Br. Jpn. For. Soc., 57, 73-75, 2009 (in Japanese).

Takanashi, S., Kosugi, Y., Tanaka, Y., Yano, M., Katayama, T., Tanaka, H., and Tani, M.: $\mathrm{CO}_{2}$ exchange in a temperate Japanese cypress forest compared with that in a cool-temperate deciduous broad-leaved forest, Ecol. Res., 20, 313-324, 2005.

Tamate, S., Kashiyama, T., Sasanuma, T., Takahashi, K., and Matsuoka, H.: On the distribution maps of forest wind damage by Typhoon No. 15, 1954 in Hokkaido, Bull. Gov. For. Exp. Sta., 289, 43- 67, 1977 (in Japanese with English summary).

Thomas, M. V., Malhi, Y., Fenn, K. M., Fisher, J. B., Morecroft, M. D., Lloyd, C. R., Taylor, M. E., and McNeil, D. D.: Carbon dioxide fluxes over an ancient broadleaved deciduous woodland in southern England, Biogeosciences, 8, 1595-1613, doi:10.5194/bg-8-1595-2011, 2011.

Tsuboki, K., Yoshioka, M. K., Shinoda, T., Kato, M., Kanada, S., and Kitoh, A.: Future increase of supertyphoon intensity associated with climate change, Geophys. Res. Lett., 42, 646-652, doi:10.1002/2014GL061793, 2015.

Turner, M. G.: Disturbance and landscape dynamics in a changing world, Ecology, 91, 2833-2849, 2010.

Urbanski, S., Barford, C., Wofsy, S., Kucharik, C., Pyle, E., Budney, J., McKain, K., Fitzjarrald, D., Czikowsky, M., and Munger, J. W.: Factors controlling $\mathrm{CO}_{2}$ exchange on timescales from hourly to decadal at Harvard Forest, J. Geophys. Res., 112, G02020, doi:10.1029/2006JG000293, 2007.

Usbeck, T., Wohlgemuth, T., Dobbertin, M., Pfister, C., Bürgi, A., and Rebetez, M.; Increasing storm damage to forests in Switzerland from 1858 to 2007, Agr. Forest Meteorol., 150, 47-55, 2010.

Utsugi, H., Tobita, H., Maruyama, Y., and Ishizuka, M.: Spatial and seasonal variation in leaf mass per area and their relationship to leaf nitrogen in a secondary northern hardwood forest in Japan, Phyton (Horn, Austria), 45, 245-251, 2005.

Utsugi, H., Iida, S., Tobita, H., Uemura, A., Ishizuka, M., and Tanaka, N.: The net primary production of boreal deciduous forest for 25 years in northern Japan, Trans. Mtg. Hokkaido Br. Jpn. For. Soc., 55, 35-37, 2007 (in Japanese).

Utsugi, H., Tobita, H., Kitao, M., Uemura, A., Kitaoka, S., Sakata, T., Iida, S., and Watanabe, T.: The quantitative estimate of stem and branch respiration in boreal deciduous forest of northern Japan, Trans. Mtg. Hokkaido Br. Jpn. For. Soc., 56, 4749, 2008 (in Japanese).
Utsugi, H., Takahashi, M., Tobita, H., Uemura, A., Kitaoka, S., Sakata, T., Takao, G., and Watanabe, T.: Relation between intensity of crown disturbance and forest structure using LIDAR data, Trans. Mtg. Hokkaido Br. Jpn. For. Soc., 57, 69-71, 2009 (in Japanese).

Utsugi, H., Sakata, T., Kitaoka, S., Tobita, H., and Uemura, A.: The quantitative estimation of stem and branch decomposition in boreal deciduous forest of northern Japan -4 years period after 18th typhoon in 2004, Trans. Mtg. Hokkaido Br. Jpn. For. Soc., 58, 83-86, 2010 (in Japanese).

Utsugi, H., Harayama, H., Kitaoka, S., Uemura, A., Mizoguchi, Y., and Yamanoi, K.: The estimation of biomass production of Sasa in boreal deciduous forest of northern Japan -8 years period after 18th typhoon in 2004, Bor. For. Res., 61, 81-84, 2013 (in Japanese).

Valentini, R., Matteucci, G., Dolman, A. J., Schulze, E. D., Rebmann, C., Moors, E. J., Granier, A., Gross, P., Jensen, N. O., Pilegaard, K., Lindroth, A., Grelle, A., Bernhofer, C., Grunwald, T., Aubinet, M., Ceulemans, R., Kowalski, A. S., Vesala, T., Rannik, U., Berbigier, P., Loustau, D., Gumundsson, J., Thorgeirsson, H., Ibrom, A., Morgenstern, K., Clement, R., Moncrieff, J., Montagnani, L., Minerbi, S., and Jarvis, P. G.: Respiration as the main determinant of carbon balance in European forests, Nature, 404, 861-865, 2000.

Vickers, D. and Mahrt, L.: Quality control and flux sampling problems for tower and air craft data, J. Atmos. Ocean. Tech., 14, 512-526, 1997.

Webb, E. K., Pearman, G. I., and Leuning, R.: Correction of flux measurements for density effects due to heat and water vapour transfer, Q. J. Roy. Meteor. Soc., 106, 85-100, 1980.

Welp, L. R., Randerson, J. T., and Liu, H. P.: Seasonal exchange of $\mathrm{CO}_{2}$ and $\delta^{18} \mathrm{O}-\mathrm{CO}_{2}$ varies with postfire succession in boreal forest ecosystems, J. Geophys. Res., 111, G03007, doi:10.1029/2005JG000126, 2006.

Yasuda, Y. and Watanabe, T.: Comparative measurements of $\mathrm{CO}_{2}$ flux over a forest using closed-path and open-path $\mathrm{CO}_{2}$ analysers, Bound.-Lay. Meteorol., 100, 191-208, 2001.

Yasuda, Y., Watanabe, T., Ohtani, Y., Okano, M., and Nakayama, K.: Seasonal variation of $\mathrm{CO}_{2}$ flux over a broadleaf deciduous forest, J. Japan Soc. Hydro. Water Resour., 11, 575-585, 1998 (in Japanese with English summary).

Yasuda, Y., Saito, T., Hoshino, D., Ono, K., Ohtani, Y., Mizoguchi, Y., and Morisawa, T.: Carbon balance in a cooltemperate deciduous forest in northern Japan: seasonal and interannual variations, and environmental controls of its annual balance, J. Forest Res., 17, 253-267, 2012. 